\title{
1913-2013: a un siglo de 'El Psico-análisis' según Janet
}

\section{3-2013: the centennial of Janet's 'Psycho-analysis'}

\section{Alejandro Antonio Dagfal*}

Universidade de Buenos Aires-UBA, Buenos Aires, Argentina.

\begin{abstract}
RESUMO
Este trabalho ocupa-se, em detalhes, com a célebre crítica de Janet à psicanálise, de 1913. Em primeiro lugar, detém-se em seus antecedentes, particularmente no período 1893-1895, no que se produziram os primeiros intercâmbios entre Janet e Freud. Em segundo lugar, reconstrói-se o contexto dessa crítica: o Congresso Internacional de Medicina de Londres, tendo em conta o lugar que Janet e Freud ocupavam nesse momento no plano internacional. Em terceiro lugar, examina-se a crítica em si, questionando as interpretações estabelecidas sobre o tema. Finalmente, avalia-se o impacto dessa crítica no período 1913-1915, a partir de sua publicação em cidades tão distintas como Londres, Boston, Paris, Viena e La Plata. Por outra parte, no plano conceptual, este trabalho destaca a especificidade dos termos "análise psicológica" e "subconsciente", que erroneamente costumam opor-se, de maneira simétrica, à psicanálise e ao inconsciente freudiano.
\end{abstract}

Palavras-chave: Janet, Freud, Psicanálise, Subconsciente.

\begin{abstract}
This paper deals with Janet's famous critique of psychoanalysis, of 1913. In the first place, it looks into its background, particularly the period 18931895, in which the earliest exchanges between Janet and Freud took place. Secondly, it reconstructs the context of that critique: the International congress of Medicine held in London, trying to take into account the place that Janet and Freud occupied at the time in the international sphere. Furthermore, the critique itself is examined in detail, questioning established interpretations on the subject. Finally, an assessment of the impact of that critique is provided, paying attention to its publication, between 1913 and 1915, in cities as different as London, Boston, Paris, Vienna and La Plata. In addition, on a theoretical level, this paper points out the specificity of terms such us "psychological analysis" and "subconscious", that have mistakenly been opposed, in a symmetrical manner, to psychoanalysis and Freudian unconscious.
\end{abstract}

Keywords: Janet, Freud, Psychoanalysis, Subconscious.

\section{Introducción}

A menudo se ha presentado el problema de las diferencias entre Janet y Freud como una apasionante querella por la paternidad del psicoanálisis, que habría terminado saldándose a favor del médico 
vienés, en razón de la fama mundial que finalmente adquirieron sus teorías, y del olvido en que cayeron las ideas janetianas. No obstante, esta perspectiva tiende a relativizar la importancia de las concepciones de Janet, centrando su atención sobre el psicoanálisis. Por esa razón, en este trabajo trataremos de mostrar distintos aspectos de una larga disputa (primero teórica y luego también personal) entre los inventores de dos teorías divergentes sobre las neurosis y sus modos de tratamiento, que, pese a tener varios puntos de contacto (sobre todo en sus orígenes), rápidamente se fueron diferenciando.

En ese sentido, luego de pasar revista a la primera gran sistematización teórica de Janet, de 1889, trataremos de mostrar cómo se desarrollaron sus diferencias con Freud. Con ese fin, nos detendremos en dos momentos cruciales: el período 1893-1895, por un lado, en el que ambos autores centraban sus preocupaciones en el origen traumático de la histeria ( $\mathrm{y}$, por lo tanto, comenzaron a citarse asiduamente), y el bienio 1913-1915, en el que Janet formuló su célebre crítica del psicoanálisis en el Congreso Internacional de Medicina de Londres, de 1913, que implicó ásperos debates "por interpósita persona", tanto en el evento mismo como en publicaciones inmediatamente posteriores, que trataremos de examinar. En esos dos períodos, si se sigue de cerca la bibliografía primaria, salta a la vista que las posiciones de uno y de otro fueron cambiando (Freud muy rápidamente y Janet de manera más lenta). Por ese motivo, trataremos de explicitar esos virajes, rescatándolos como un problema a estudiar más que como parte de una disputa carente de aristas y resuelta de antemano.

\section{El automatismo psicológico: la histeria y la persistencia subconsciente del pasado}

En 1889, antes de conocer los trabajos de Breuer y Freud, que aún no habían sido publicados, Pierre Janet defendió una tesis de filosofía (para un doctorado en letras) sobre "el automatismo psicológico". El subtítulo de esa tesis definía muy bien su proyecto: se trataba de un "ensayo de psicología experimental sobre las formas inferiores del alma humana" (JANET, 1889). Es que, a partir de esas formas elementales, rudimentarias y simples, según un principio canónico del evolucionismo, esperaba dar cuenta de las formas más elevadas y complejas. Esas formas inferiores, a su vez, remitían a lo que él denominaba una "actividad automática" (conservadora), que oponía a una "actividad sintética" (creadora o innovadora). Esta última, encarnada por "la voluntad, la resolución y el libre albedrío", no podía explicarse sino a través del automatismo en el que se apoyaba, con el que mantenía un equilibrio conflictivo (del mismo modo en que el 
presente podía entrar en conflicto con el pasado) ${ }^{1}$.

No obstante, la actividad regular y determinada, pese a ser automática, no era mecánica. Para Janet, en el hombre, hasta el más mínimo movimiento exterior implicaba cierto grado de conciencia, de sensibilidad y de inteligencia. En ese sentido, afirmaba que su fin no sólo era "demostrar que hay una actividad humana que merece el nombre de automatismo, sino que también es legítimo llamarlo automatismo psicológico" (JANET, 1889, p. 3). Al mismo tiempo, ese concepto iba a darle las herramientas para pensar toda una serie de fenómenos patológicos que ponían en cuestión la unidad de la voluntad y de la conciencia. En efecto, "movimientos incoherentes y compulsivos, actos inconscientes ignorados por aquél que los realiza, deseos impulsivos contrarios a la voluntad a los que el sujeto no puede resistirse" ( $p .4$ ) podían hacerse inteligibles a partir del estudio de las formas inferiores de la actividad, con la ayuda del método de las ciencias naturales, esto es, la observación y la experimentación ${ }^{2}$. Sin embargo, en este intento de hacer de la psicología una ciencia por derecho propio, el filósofo francés se encontraba con una gran dificultad: "es que en la serie de las asociaciones, a cada instante, nos chocamos con representaciones inconcientes" "3. Para muchos contemporáneos (como su maestro Ribot), ese tipo de representaciones constituían fenómenos fisiológicos, a los cuales debían reducirse los fenómenos del espíritu. Para Janet, empero, las leyes de la conciencia no podían extraerse de los hechos físicos. "Para acceder a fenómenos simples, precisos y completos, hay que observarlos en los otros apelando a la psicología objetiva. Sin duda, sólo conocemos indirectamente los fenómenos psicológicos de los otros, y la psicología no podría comenzar por ese estudio. Aún así, a partir de los actos, los gestos, el lenguaje, podemos inducir [sic] su existencia, al igual que el químico determina los elementos de los astros según los rayos del espectro" (JANET, 1889, p. 5). De este modo, Janet comenzaba a legitimar todo un campo de investigaciones "conjeturales", que iba a ser el suyo, pero también el de Breuer y Freud.

Lo cierto es que, a partir de estas premisas, Janet dedicaría su vida al estudio de la psicopatología, destacando el hecho de que "si se conocieran bien las enfermedades mentales, no sería difícil estudiar la psicología normal" (p. 5). No obstante, este conocimiento de los experimentos que la naturaleza ofrecía a la observación a través de las enfermedades era muy lento y poco preciso. Por esa razón, según él, las verdaderas experiencias psicológicas requerían la modificación artificial del estado de conciencia de una persona, "de manera determinada y calculada de antemano" (p. 6). Se inscribía así en la senda de Moreau de Tours (que había experimentado con el haschisch) y de Taine (quien había indicado los usos del sonambulismo en psicología); pero también de los magnetizadores. 
En esa línea, la opción metodológica de Janet apuntaba al sueño hipnótico, por lo que, para desmarcarse de eventuales acusaciones de charlatanismo y superchería, explicitaba las condiciones en las que lo había utilizado: "Los sujetos con los cuales se han realizado estos estudios eran casi todos... mujeres afectadas por enfermedades nerviosas más o menos graves, particularmente por esa enfermedad muy variable que se designa con el nombre de histeria. Esas neurosis, al tener como carácter principal una gran inestabilidad mental, nos ofrecen, tanto por los accidentes naturales que ocasionan como por la predisposición al sonambulismo que engendran, el campo más favorable para los estudios experimentales de psicología y, sobre todo, para los estudios sobre el automatismo" (p. 7-8) ${ }^{4}$.

Por otra parte, agregaba que en razón de la extrema variabilidad de ese tipo de casos, para apreciar las distintas fases de la enfermedad, había que estudiarlos durante largo tiempo. Esas fueron las condiciones que Janet trató de cumplir en sus investigaciones sobre "catorce mujeres histéricas e hipnotizables, cinco hombres afectados por la misma enfermedad y otros ocho individuos que padecían de alienación mental o de epilepsia" (p. 8). No obstante, las experiencias fueron repetidas particularmente con cuatro sujetos: Léonie, Lucie, Rose y Marie. "Estas cuatro personas, más que todas las otras, nos parecieron satisfacer las condiciones de una buena experiencia psicológica. Estudiadas durante mucho tiempo, eran perfectamente conocidas en todos los detalles de su enfermedad y de su carácter; examinadas con precaución y sólo por personas competentes, fueron modificadas lo menos posible por ejemplos o palabras imprudentes" (p. 9).

A partir del estudio de estos casos, Janet comprobó, por un lado, que los accidentes histéricos implicaban una suerte de "desagregación de la personalidad", con el surgimiento de una "segunda forma de existencia" 5. Si bien el desarrollo de este "grupo secundario de fenómenos" ya podía constatarse en los sueños o en los estados de conciencia inducidos por el éter, el cloroformo o el alcohol, se hacía mucho más patente y duradero en los estados mórbidos. Por otra parte, "aunque este hecho no siempre se haya observado, es posible, por medio del hipnotismo, llevar al sujeto a sus diversas personalidades anormales, devolviéndole el carácter y los recuerdos que tenía en ese estado" ( $p$. 123). Finalmente, para nuestro autor, estos fenómenos mórbidos (que iban desde la catalepsia hasta la anestesia, pasando por la parálisis y las ideas fijas) obedecían a un rasgo propio de los neurópatas en general y de los histéricos en particular, que él dio en llamar "angostamiento del campo de la conciencia". "Este carácter es producido, según nuestra hipótesis, por esta debilidad de síntesis psíquica, que llega más lejos de lo habitual, y que no les permite reunir en una misma percepción personal un gran número de fenómenos sensitivos que realmente ocurren en 
ellos" (p. 208). Si bien en este momento aún no decía gran cosa sobre el origen de esa debilidad, ya quedaba en claro que, en la psicopatología, se producía un triunfo del pasado sobre el presente. Un "espíritu normal" sólo dejaba librados al automatismo (y a la desagregación de los fenómenos subconscientes) algunos actos inferiores, cuya repetición no era problemática ni sintomática, mientras dedicaba la mayor parte de sus fuerzas a la adaptación a las condiciones actuales. Un espíritu enfermo, en cambio, al ver debilitada su capacidad de síntesis, no lograba poner límite "a esa fuerza automática que quiere mantener inmutables las emociones y las percepciones del pasado" (p. 487).

Hasta aquí, los primeros desarrollos teóricos de un filósofo que había ejercido la docencia secundaria en Le Havre y comenzaba a destacarse por sus trabajos sobre las neurosis, a la par que, siguiendo el mandato ribotiano, iniciaba sus estudios de medicina en París, bajo la dirección de Jean-Martín Charcot.

\section{Primeras referencias de Freud a Janet. Del reconocimiento a la crítica.}

El temprano interés de Freud por las ideas janetianas no necesita ser demostrado. Basta con remitirse a sus escritos posteriores a 1893 para encontrar sus primeras referencias a quien fuera discípulo de Ribot y de Charcot ${ }^{6}$. A partir de ese año, en su abordaje "dinámico" de la histeria, Freud iba a recurrir a Janet insistentemente, tanto más cuanto que él mismo, por oposición a la escuela vienesa, buscaba inscribirse en la tradición charcotiana ${ }^{7}$. Así, en su "Estudio comparativo de las parálisis motrices orgánicas e histéricas" (basado en observaciones propias, aunque efectuadas en la Salpêtrière por indicación de Charcot), Freud afirmaba no poder dejar de asociarse plenamente a la opinión que Janet había expuesto en los últimos números de los Archives de Neurologie, tanto sobre las parálisis histéricas como sobre las anestesias y los síntomas psíquicos ${ }^{8}$. "Con Janet, afirmamos que en las parálisis histéricas, como en las anestesias, es la concepción vulgar, popular, de los órganos y del cuerpo en general la que entra en juego. [...] La lesión de la parálisis histérica será, pues, una alteración, por ejemplo, de la concepción o idea del brazo. Pero, ¿de qué clase es esta alteración para producir la parálisis? Considerada psicológicamente, la parálisis del brazo consiste en que la concepción del brazo queda imposibilitada de entrar en asociación con las demás ideas que constituyen el yo, del cual el cuerpo del individuo forma una parte importante. La lesión sería, pues, la abolición de la accesibilidad asociativa de la concepción del brazo" (FREUD, 1893a, p. 199).

Ese mismo año, en el mes de agosto, en su homenaje póstumo a 
Charcot, Freud le atribuía el lugar de "primer esclarecedor" de la histeria, en la medida en que había sabido distinguir las parálisis histéricas de las orgánicas, había logrado reproducir artificialmente las primeras (por medio de la sugestión hipnótica) y había demostrado que tales parálisis "eran consecuencia de representaciones dominantes en el cerebro del enfermo" (FREUD, 1893b, p. 22-23). Según él, así quedaba explicado, por primera vez, "el mecanismo de un fenómeno histérico". "A este incomparable resultado de la investigación clínica enlazaron sus estudios Janet, discípulo de Charcot; Breuer y otros, desarrollando una teoría de la neurosis coincidente con el concepto medieval de esta afección, con la única diferencia de sustituir el 'demonio' por una fórmula psicológica" (FREUD, 1893b, p. 23). Freud reconocía entonces a Janet como discípulo de Charcot, al mismo tiempo que lo diferenciaba de este último, en la medida en que, al alejarse en parte de las doctrinas hereditarias de su maestro, había logrado desarrollar una concepción propia de la neurosis que, a su vez, abría la posibilidad de una práctica psicoterapéutica, que aún estaba en ciernes.

Pero las referencias más precisas a Janet (y ciertamente las más conocidas) se dieron en la "comunicación preliminar" sobre los mecanismos psíquicos de los fenómenos histéricos, que había sido publicada conjuntamente por Josef Breuer y por Freud también en 1893, en Berlín, en los primeros dos números de enero del Neurologisches Centralblatt (y reeditada dos años después en los Studien über Hysterie): "Cuando más detenidamente fuimos estudiando estos fenómenos, más firme se hizo nuestra convicción de que aquella disociación de la conciencia, que tan singular se nos muestra como 'double consciencie' en los conocidos casos clásicos, existe de un modo rudimentario en toda histeria, siendo la tendencia a esta disociación, y con ella a la aparición de estados anormales de conciencia, que reuniremos bajo el calificativo de 'hipnoides', el fenómeno fundamental de esta neurosis. En esta opinión coincidimos con Binet y con los dos Janet [Jules y Pierre], sobre cuyas singularísimas observaciones en sujetos anestésicos carecemos, por lo demás, de experiencia (BREUER; FREUD, 1893, p. 29) ${ }^{9}$.

En este momento, es claro que Freud (junto con Breuer) suscribía sin ambages a la concepción según la cual la tendencia a la disociación de la conciencia (es decir, a la formación de estados hipnoides) era la condición principal para la formación de síntomas histéricos. Sin embargo, apenas un año después, en "Las neuropsicosis de defensa", basándose en ese mismo trabajo de 1893, iba a decir algo muy diferente, dejando de lado la tendencia (término de filiación ribotiana y janetiana) para poner el énfasis en los estados: "A la teoría de Janet, contra la cual pueden elevarse, a nuestro juicio, numerosas objeciones ${ }^{10}$, se opone la desarrollada por J. Breuer en nuestra comunicación sobre la histeria. Según Breuer, es 'base y condición' 
de la histeria la existencia de singulares estados de conciencia oniriformes, con disminución de la facultad asociativa, para los cuales propone el nombre de 'estados hipnoides'. La disociación de la conciencia es entonces una disociación secundaria adquirida, motivada por el hecho de que las representaciones surgidas en los estados hipnoides se hallan excluidas del comercio asociativo con los restantes contenidos de la conciencia" (FREUD, 1894, p. 174).

Este desplazamiento de la condición de la disociación (la tendencia) a la ocasión en la que esa disociación se producía (los estados hipnoides), no sólo traía aparejada una inversión respecto de su carácter (primario o secundario), sino que implicaba a su vez todo un cambio de juicio respecto del peso que Janet aún daba a la herencia, tal como Freud iba a aclarar en 1895, a propósito del caso Emmy: "Confieso también que me es imposible hallar en el historial de esta paciente el menor rasgo de 'disminución funcional psíquica', de la que P. Janet hace depender la génesis de la histeria. La disposición histérica consistiría, según este autor, en un angostamiento anormal del campo de la conciencia (resultante de la degeneración hereditaria), que da ocasión a la negligencia de series enteras de percepciones $y$, ulteriormente, a la disociación del yo y a la organización de personalidades secundarias" [...]. "A mi juicio, ha elevado aquí Janet, erróneamente, estados resultantes de la modificación histérica de la conciencia a la categoría de condiciones primarias de la histeria" (FREUD, 1895, p. 63).

Se operaba así, en apenas dos años, un giro considerable respecto de lo afirmado en 1893, cuando Breuer y Freud destacaban la tendencia a la disociación como "fenómeno fundamental" en toda histeria, pasando rápidamente a una concepción según la cual Janet, equivocadamente, habría invertido el orden de los factores, al sostener que el producto de los mecanismos histéricos ocupaba el lugar de condición de posibilidad de los síntomas. Si se considera que los intercambios entre Freud y Janet sobre las neurosis comenzaron de esta manera ambigua, con elogios que luego se convertían en críticas, no es de extrañar que, durante casi medio siglo, la relación entre ambos autores estuviera marcada por ese mismo sino, entre el franco reconocimiento, el recelo, la ironía y la rivalidad abierta.

\section{Primeras referencias de Janet a Freud. El "análisis psicológico" revisitado.}

Un mes antes de la defensa de su tesis doctoral en medicina, en junio de 1893, el filósofo francés publicó un artículo sobre "definiciones recientes de la histeria" en el cual, por primera vez, tomaba nota de los comentarios que Breuer y Freud habían realizado sobre sus teorías en el mes de enero ${ }^{11}$ : "El trabajo más importante que ha 
confirmado nuestros viejos estudios es sin duda el artículo de los Sres. Breuer y Freud, recientemente aparecido en el Neurologisches Centralblatt. Estamos muy contentos de que estos autores, en sus investigaciones independientes, hayan podido verificar las nuestras con tanta precisión, y les agradecemos su amable cita. Muestran con numerosos ejemplos que los diversos síntomas de la histeria no son manifestaciones espontáneas, idiopáticas de la enfermedad, sino que están en estrecha conexión con el trauma provocador" (JANET, 1893c, p. 437, apud NICOLAS, 2004, p. 6). Dicho de otro modo: luego de echar un rápido vistazo al conjunto de las nuevas teorías sobre la histeria, el profesor francés destacaba una que no hacía más que confirmar la propia, que era más antigua (cosa que se encargaba de señalar con mucha politesse).

Esta primera referencia de Janet a las teorías de Breuer y Freud marcaría el tono de las numerosas citas por venir. En primer lugar, Janet iba a destacar siempre la anterioridad de sus teorías sobre el tema (hecho que Freud no iba a cuestionar). En segundo lugar, iba a resaltar que los vieneses verificaban sus propios hallazgos, aunque más no fuera por caminos diferentes. Por último, iba a reconocer que, en esa dirección, Breuer y Freud habían aportado observaciones clínicas de valor, aunque fueran demasiado optimistas en sus pretensiones terapéuticas (sobre todo en lo relativo al valor curativo del descubrimiento del recuerdo traumático). Al mismo tiempo, cabe recordar que, en la comunicación preliminar, el "factor sexual" aún no tenía todo el peso que Freud pronto iba a darle en la etiología de las neurosis. Por ese motivo, para un lector no advertido de lo que se expresaba entre líneas, en esta época, Janet simplemente elogiaba el trabajo de sus colegas vieneses ${ }^{12}$. Podría pensarse, incluso, que, entre el método ecléctico (basado en diversos procedimientos) propuesto por el francés y el método catártico utilizado por Breuer y Freud (que tampoco era un método unificado) no había una oposición sino una relación de complementariedad. No obstante, salvo por la incidencia de la sexualidad y la importancia del simbolismo, ya se encontraban allí la mayoría de los elementos que constituirían los pilares de la famosa crítica que Janet dirigiría al psicoanálisis dos décadas más tarde.

Volviendo entonces al breve período que se inicia en enero de 1893, el 29 de julio de ese año, Janet defendió su tesis de medicina bajo la dirección de Jean-Martín Charcot, quien iba a morir pocos días después, el 16 de agosto. Esa tesis, denominada Contribution à l'étude des accidents mentaux chez les hystériques (J ANET, 1893a), recién iba a ser publicada un año más tarde, con el título L'État mental des hystériques. Les accidents mentaux (JANET, 1894). Previamente, en 1893, simultáneamente a la defensa de de su tesis, ya había publicado una primera parte de ese trabajo, con un breve prólogo de Charcot y con el nombre L'État mental des hystériques: 
Les stigmates mentaux, que incluía las tres conferencias de 1892 mencionadas por Freud en 1893 (JANET, 1893b, 1892a, 1892b, 1892c) ${ }^{13}$. En ese prólogo, fechado en noviembre de 1892, el "patrón" de la Salpêtrière destacaba que "esos estudios, comenzados hace mucho tiempo, han sido completados en mi servicio...". "Vienen a confirmar un pensamiento expresado a menudo en nuestras clases: que la histeria es en gran parte una enfermedad mental" (CHARCOT, 1893, p. 5) ${ }^{14}$. Podría decirse que Charcot actuaba con Janet como Janet con Breuer y Freud. Esto es, elogiaba sus investigaciones en la medida en que confirmaban las propias, soslayando toda originalidad o diferencia teórica. En esta dirección, de manera indirecta, señalaba el hecho de que al menos una parte de la histeria no podía reducirse al ámbito de lo psíquico.

En este punto, no podría decirse que Charcot no hacía justicia a las ideas janetianas, tanto más cuanto que, en esta época, el médicofilósofo no sólo daba gran importancia al componente hereditario de las tendencias, sino que también ponía de relieve los "estigmas mentales", que, según la definición clásica, a diferencia de los "accidentes", eran esenciales y permanentes, es decir, constitutivos de la enfermedad (en un sentido que no permitía dejar de lado su relación con la herencia). Así, desde la introducción de Les Accidents mentaux, fechada en junio de 1893, situaba su empresa bajo los auspicios de su "eminente maestro", por lo que, sin negar la existencia de todas las alteraciones orgánicas susceptibles de encontrarse en la histeria, buscaba "poner en evidencia la perturbación psicológica que siempre las acompaña" (Janet, 1894, p. 2). Al mismo tiempo, iba a tratar de demostrar que, dentro de la aparente variedad de los accidentes histéricos, si se prestaba atención a los aspectos morales (y no ya a los orgánicos), muy fácilmente podía encontrarse una similitud que implicaba una unidad mórbida. "No será necesario, para hacerla aparente, reunir los hechos por medio de teorías o de interpretaciones psicológicas; alcanzará con yuxtaponer observaciones. Este libro no es más que un compendio de observaciones psicológicas sobre las histéricas, observaciones que han sido vinculadas entre sí." (Janet, 1894, p. 34). Aquí también puede verse el germen de una diferencia fundamental entre Janet y Freud. El afán descriptivo del primero desembocaba en una exaltación de la observación clínica, que requería de un sólido apoyo empírico (centenares de casos) y desconfiaba del espíritu de sistema. El segundo, por el contrario, basado en el estudio en profundidad de unos pocos casos, terminaría construyendo, años después, un edificio teórico tan ambicioso como complejo.

En este marco, muchas de las críticas de Janet al método catártico (e incluso, luego, al psicoanálisis) pueden entenderse tomando en consideración estos rasgos divergentes, sin necesidad de 
considerarlas como ataques ad hominem u oportunas críticas ad hoc. Por ejemplo, ya en 1889, en su tesis de filosofía (es decir, antes de conocer los trabajos de Breuer y Freud), luego de exponer sus éxitos terapéuticos con los diversos síntomas de su paciente histérica Marie, Janet expresaba: "Yo no doy a esta curación más importancia de la que merece, y no sé cuanto tiempo durará. Pero esta historia me pareció interesante para mostrar la importancia de las ideas fijas subconscientes..." (JANET, 1889, p. 440). Este escepticismo terapéutico, que atravesaría toda la obra janetiana (y se contrapondría en gran medida al entusiasmo con que Freud tomaba sus propios avances), también puede ayudar a entender la decena de comentarios que Janet dedicó a la "comunicación preliminar" en 1894, en su tesis de medicina: "En el pasado he mostrado muy a menudo que había que ir en busca, por decirlo de alguna manera, de estos fenómenos subconscientes para atacarlos, y que no se podía tratar el accidente histérico antes de haber alcanzado esas capas profundas del pensamiento en las que se disimulaba la idea fija. Me complace ver hoy que los señores Breuer y Freud expresan la misma idea. 'Es necesario, dicen, hacer conciente ese evento provocador, sacarlo a plena luz; los accidentes desaparecen cuando el sujeto se da cuenta de esas ideas fijas' ${ }^{15}$. No creo que la cura sea tan fácil, ni que baste con hacer expresar la idea fija para suprimirla; desafortunadamente, el tratamiento es mucho más delicado, pero, en todo caso, es seguro que este descubrimiento de los fenómenos subconscientes es una operación preliminar e indispensable" (JANET, 1894, p. 189-190). En otras palabras, el recuerdo y la catarsis eran condiciones necesarias pero no suficientes, de tal suerte que, a nivel terapéutico, no había que confundir la parte con el todo.

Lo anterior muestra que las críticas que Janet comenzaba a dedicar a los trabajos de Freud, en gran medida, ya se las había aplicado a sí mismo. Algo similar podría decirse sobre su posición respecto de la "falsabilidad" de las ideas científicas. Respecto de este tema, ya en 1889, al referirse a sus propias investigaciones, afirmaba que "uno de los grandes méritos de estos nuevos estudios de psicología es que son susceptibles de error. Se puede demostrar de manera rigurosa, como indudablemente se hará con muchos de estos estudios, la inexactitud involuntaria de tal o cual observación, lo erróneo de tal o cual interpretación. Ése es un mérito y una ventaja: para la mente, es satisfactorio constatar que uno se equivocó en algún punto, porque eso hace esperar que uno haya sido o sea capaz de entrever la verdad en algún otro punto. Las hipótesis generales de la filosofía no son pasibles de error [...]. Es por ello que no debemos comprometernos con esas teorías, que por su naturaleza están por encima y por fuera de toda discusión precisa (JANET, 1889, p. 479, apud VALSINER; VAN DER VEER, 2000, p. 71). Si bien estos preceptos epistemológicos no fueron esgrimidos en contra de los 
primeros estudios sobre la histeria, sí serían utilizados a rajatabla para descalificar el psicoanálisis como doctrina filosófica. Pero eso recién sucedería casi un cuarto de siglo más tarde, según veremos más adelante.

En este momento, si bien es claro que el método terapéutico empleado por Freud y Breuer era el método catártico (modificado luego por la "técnica de la presión"), solidario de una teoría de la "abreacción" que, a su vez, se apoyaba en una primera forma del "principio de constancia" (STRACHEY, 1957), del lado de Janet las cosas aparentaban ser más complejas. Aunque la gran mayoría de la bibliografía especializada utilice el rótulo de "análisis psicológico" para referirse a lo que él hacía en esta época (entre fines de los '80 y mediados de los '90), parece tratarse de una visión retrospectiva que da una importancia desmedida a un término que el mismo Janet casi no iba a utilizar a lo largo de su vida (de hecho, no aparece ni una sola vez en su tesis de filosofía y sólo una en Les États mentaux). Las escasísimas veces en las que mencionó esa expresión en sus trabajos del siglo XIX, más que a un método terapéutico, parecía hacer referencia a un análisis científico de los hechos psicológicos ${ }^{16}$. Era un primer paso indispensable en la observación clínica de cualquier hecho psicopatológico.

Por ejemplo, en 1894, para establecer la unidad de la histeria como enfermedad, esperaba que "el análisis de esos fenómenos morales" le permitiera mostrar que todas las enfermedades no se confundían entre sí, ya que la histérica no era simplemente "una alienada como todas las otras". "Sin duda, este diagnóstico es difícil; requeriría un análisis psicológico de las diferentes formas de la alienación que está muy lejos de estar terminado" (J ANET, 1894a, p. 5). E incluso, cuatro años más tarde, precisaría aún más esa misma idea: "Para comprender bien a una alienada, habría que pasar revista a todas sus facultades psicológicas, y determinar exactamente, en cada grupo de fenómenos, qué se aparta de la ley normal, del mismo modo en que se examina cada órgano físico para advertir una enfermedad orgánica. Lamentablemente, los medios de investigación son aún muy poco precisos, y las leyes normales de la psicología todavía son generales y vagas; por consiguiente, este análisis psicológico se reduce forzosamente a algunos comentarios aislados, a algunos datos aproximativos. Por insuficiente que sea esta investigación, no debemos descuidarla (J ANET, 1898, p. 36).

Es decir que el análisis psicológico, en ese período, no sólo no era presentado por Janet como su método terapéutico, sino que era apenas un equivalente (limitado) del examen físico en las enfermedades orgánicas. Él mismo se iba a ocupar de dar cuenta de cuál consideraba "su método": "Estoy convencido de que es por el estudio de las experiencias naturales, más que por el de las teorías y las mediciones matemáticas que llegaremos a comprender nuestra 
inteligencia y nuestra acción...". "Es por eso que he tratado de aplicar a estos estudios [sobre las ideas fijas] un método que he tomado prestado de la clínica médica y que me parece muy apropiado para las investigaciones en psicología experimental: el de las observaciones individuales. Para alguien como yo, que confiesa no comprender las teorías generales de las ideas fijas, cada enfermo es interesante en sí mismo y requiere ser analizado aisladamente" (JANET, 1898, p. 1-2). Con esta afirmación, Janet se desmarcaba por un lado de Charcot, ya que la observación individual contrastaba con las presentaciones de enfermos de carácter público, tan caras a su maestro. Por otra parte, una vez más, se alejaba del espíritu de sistema de sus colegas vieneses. Y, finalmente, se apartaba también de la obsesión cuantificadora de la psicología diferencial norteamericana y la psicología experimental alemana. No obstante, se inscribía sin hesitaciones en la tradición patológica francesa.

Más allá de la observación individual, a nivel práctico, al carecer de un modelo terapéutico unificado, Janet recurría, por ensayo y error, a toda una serie de técnicas y procedimientos, empezando por la detección del recuerdo traumático, la disociación de ese recuerdo de la idea fija asociada y su supresión o sustitución por sugestión hipnótica ${ }^{17}$. Asimismo, como puede verse en sus casos más célebres (Léonie, Marcelle, Irène, Justine, Lucie, Marie, etc.), estos procedimientos también incluían la utilización de la escritura automática, la dirección de conciencia, la educación de la atención voluntaria y, en suma, todo aquello que tendiera al fortalecimiento de la capacidad de síntesis del sujeto, permitiéndole reconstituir su unidad mental ${ }^{18}$. En sus años de madurez, en su autobiografía de 1930, Janet ni siquiera iba mencionar el análisis psicológico. "En esa época [los años '80], me resolví a examinar a los pacientes tan lejos como pudiera sin la molestia de testigos. Además, adquirí un hábito que siempre mantuve: el de tomar nota constantemente durante las sesiones de todo lo que pasaba, escribiendo las palabras pronunciadas por los testigos, por el paciente, por mí mismo, y absteniéndome de tomar en cuenta cualquier otro recuerdo, a menos que coincidiera exactamente con alguna nota escrita. Mi psicología se transformó en la "psicología del bolígrafo", y, lamentablemente, mis descripciones de los pacientes se hicieron inusualmente largas y pesadas, por la reproducción exacta de las palabras que se decían y que yo anotaba" (JANET, 1930, p. 126).

Considerando todo lo anterior, llama la atención que Henri Ellenberger, en su obra monumental (y excelentemente documentada) sobre la historia de la psiquiatría dinámica, haya titulado el extenso capítulo (de casi cien páginas) dedicado al filósofo y médico francés "Pierre Janet y el análisis psicológico". De hecho, en el apartado dedicado específicamente al análisis psicológico, después de examinar varios casos clínicos de los años '80 y '90, terminaba 
reconociendo que, "cuando hablaba de análisis psicológico, Janet nunca afirmaba que éste fuera su propio método" (ELLENBERGER, 1976 , p. 429). No obstante, en una nota al pie, sin aportar ninguna fuente específica, aclaraba que el análisis psicológico de Janet "tuvo desde el principio implicaciones terapéuticas, pero, como todavía no había comenzado sus estudios médicos, no podía hacer resaltar este aspecto de su trabajo" (ELLENBERGER, 1976, p. 427).

Sin embargo, lo cierto es que en 1907 y 1908, cuando Janet ya era un médico de fama internacional, todavía utilizaba esa expresión en un sentido muy general e inespecífico, tal como puede apreciarse en el curso que dictó durante esos años en su cátedra de Psicología Experimental y Comparada en el Collège de France, destinado al "análisis psicológico y la crítica de los métodos de psicoterapia" (JANET, 1908a). Pese a lo que ese título pueda sugerir (que el análisis psicológico implicaría un método oponible al de otras psicoterapias), en realidad, Janet dedicó sus clases a estudiar diversos procedimientos terapéuticos (desde las curas milagrosas hasta el hipnotismo, pasando por la gimnasia, la educación de la sensibilidad y la emotividad, "y las diversas excitaciones que se proponen elevar el nivel mental") ${ }^{19}$. Del mismo modo, entre 1908 y 1911, iba a dedicar sus cursos al "análisis psicológico" de la emoción, las tendencias y la percepción (JANET, 1909, 1910, 1911). Es decir que el análisis psicológico, para nuestro autor, seguía constituyendo un método de estudio (analítico, por cierto), pero no un método terapéutico. Como veremos más adelante, recién en 1913, finalmente, Janet utilizaría esa apelación para comparar su forma de ejercer la psicoterapia con el método propuesto por Freud.

\section{El congreso de Londres}

La célebre crítica de Janet al psicoanálisis se produjo en el marco del "XVII Congreso Internacional de Medicina", que tuvo lugar en Londres, entre el 7 y el 12 de agosto de 1913. Al profesor francés se le había solicitado que presentara un informe sobre las ideas freudianas en la sección XII, dedicada a la psiquiatría ${ }^{20}$. Freud, por su parte, no iba a concurrir, aunque estaría representado por dos de sus discípulos más notorios: Carl Jung, quien aún presidía la International Psychoanalytical Association (aunque semanas después iba a romper con Freud de manera estridente) y Ernest Jones (futuro presidente de la IPA durante dos décadas y biógrafo oficial de su fundador). ¿Pero quiénes eran Janet y Freud en esa época? ¿Qué lugar ocupaban en el plano internacional? Hacia 1900, el médico y filósofo francés ya había alcanzado gran notoriedad, y sus trabajos eran citados por los principales especialistas de su campo. Después de reemplazar interinamente a Théodule Ribot, entre 1895 y 1897, 
en su cátedra del Collège de France, en 1902 lo sucedió de manera definitiva, contando para ello con el apoyo de Henri Bergson ${ }^{21}$. A las clases de sus cursos (que cambiaban de tema cada año) asistía un público nutrido, que incluía numerosos visitantes extranjeros. En 1904, con su amigo Georges Dumas, fundó el Journal de Psychologie Normale et Pathologique, la segunda revista francesa dedicada a la psicología científica (después de L'Année psychologique, creada por Alfred Binet en 1895) (CARROY; PLAS, 2008). Ese mismo año fue invitado por primera vez a EEUU, en ocasión de la Exposición Internacional de Saint Louis, Missouri, donde dio una conferencia sobre psicopatología en el marco del International Congress of Art and Science, además de otras en Boston y Chicago. Dos años después fue invitado por la universidad de Harvard para dar una quincena de conferencias sobre la histeria (JANET, 1907). En 1907, finalmente, le fue confiada una de las sesiones (dedicada a la génesis de la histeria) del "Primer Congreso Internacional de Psiquiatría, Neurología, Psicología y Asistencia de los alienados", que tuvo lugar en Amsterdam, en el mes de septiembre (JANET, 1908). Allí participaron también los otros dos protagonistas que, seis años después, volverían a encontrarse en el Congreso de Londres en los mismos roles: Carl Jung (como conferencista) y Ernest J ones (como asistente y comentador). No obstante, en esa oportunidad, el tono de las intervenciones fue muy distinto. Mientras Jung afirmaba que "los presupuestos teóricos de la investigación freudiana residen, sobre todo, en los hallazgos de los experimentos de Janet", J ones se refería al "notable ensayo del profesor Janet, que no ha recibido la atención que se merece" (ELLENBERGER, 1976, p. 895-896) ${ }^{22}$. Si a esto se suma el rol estelar que le cupo a Janet en los congresos internacionales de psicología de Roma (el 5o, en 1905) y Ginebra (el 6으, en 1909), se puede tener una idea más acabada de cuál era el lugar que ocupaba en ese momento.

En cuanto a Freud, su destino estaba emparentado con el creciente reconocimiento internacional del que gozaba el psicoanálisis, después de sus inicios marginales en Europa central. Es claro que las ideas freudianas no tenían en su cuna el mismo prestigio que empezaban a adquirir en otras partes del mundo. En Austria y Alemania, por ejemplo, tanto el ámbito clínico como el académico ostentaban una organización secular y jerárquica, con figuras y teorías sólidamente instaladas, por lo cual, en esos países, los espacios institucionales resultaban muy poco permeables a nuevas ideas como las psicoanalíticas (HALE, 1978). Por el contrario, en Estados Unidos, la situación era exactamente la opuesta. Como ejemplo, baste recordar que, en 1909, Freud había sido invitado por Stanley Hall (fundador de la American Psychological Association) a dar cinco conferencias en ocasión del vigésimo aniversario de la Clark University (por la que Janet ya había pasado en 1906) ${ }^{23}$. Esto contrastaba con el 
sesquicentenario de la Universidad de Leipzig, al que Freud también había sido invitado. En todo caso, el psicoanálisis iba a obtener en la joven psiquiatría norteamericana y en el sistema universitario de EEUU, en vías de organización, el reconocimiento del que había carecido en el viejo continente. $Y$ esto como paso previo a una implantación cultural cada vez más extendida.

Por otra parte, en los últimos años se habían creado asociaciones analíticas en Zurich (1907), Berlín y Viena (1908), Nueva York y EEUU (1911) y varias revistas. Asimismo, en 1910, en el Congreso de Nuremberg, se decidió la creación de la International Pychoanalytical Association, lo cual implicaba una creciente institucionalización de un movimiento que había comenzado de manera muy humilde e informal, y que muy rápidamente se había dotado de una estructura supranacional (no exenta de conflictos políticos, disensos teóricos y tensiones entre asociaciones). En resumen, podría decirse que Janet y Freud eran sin duda dos de los representantes más destacados de la psiquiatría dinámica de principios del siglo XX. Sin embargo, el lugar que ocupaban no era equivalente. Janet era un clásico académico, un profesor universitario que gozaba del máximo prestigio en el seno de las instituciones europeas tradicionales, donde sus investigaciones constituían una referencia científica altamente respetable. Freud, por el contrario, era el líder de un movimiento atípico, que había prosperado por fuera del establishment médico y del ámbito académico, que nunca habían aceptado de buen grado ideas y prácticas que se apartaban claramente de los cánones imperantes. Al mismo tiempo, era indudable que el psicoanálisis estaba en vías de expansión y que, con su carácter sui generis, prometía nuevas respuestas para viejos problemas, suscitando la curiosidad de un público que iba mucho más allá del grupo restringido de los especialistas. En ese sentido, la reputación de Janet y la fama de Freud tenían orígenes muy distintos.

En cuanto a Jung y Jones, los principales representantes del psicoanálisis en el congreso, al que Freud decidió no asistir, ambos se encontraban en una situación compleja. Jung venía distanciándose de Freud aceleradamente desde el año anterior, en que había dado una serie de conferencias en Nueva York, en las que había puesto en evidencia sus diferencias teóricas sobre el carácter sexual de la libido y la importancia de la represión, más claramente aún que en su libro Transformaciones y símbolos de la libido (JUNG, 1912). La desconfianza de Freud ya era manifiesta y la ruptura definitiva parecía inminente. Jones, por su parte (que había entrado en contacto con Freud a través de Jung), acababa de volver a Londres luego de un exilio de cuatro años en Toronto (1908-1912), motivado por denuncias de sus pacientes. A su vez, en Canadá, había sido denunciado por una alumna de la universidad, por lo que regresó a Gran Bretaña. En esa época, intimado por Freud, debió realizar un 
rápido análisis con Sandor Ferenczi, en Budapest (GROSSKURTH, 1990). No obstante lo anterior, Jones se perfilaba como el gran artífice de la organización institucional del psicoanálisis y como el hombre de confianza de Freud para estos menesteres. En 1911 fue miembro fundador de la American Psychoanalytical Association, y, en 1912, luego de las disidencias de Adler y Stekel, y en medio de la disputa con Jung, logró convencer a Freud de la necesidad estratégica de crear un "comité secreto" compuesto por los discípulos más cercanos (ROUDINESCO ; PLON, 1997).

Respecto del congreso en sí, para destacar su relevancia y su alcance verdaderamente internacional, cabe citar la manera en que lo anunciaba, varios meses antes, un periódico neocelandés: “EI Congreso Internacional de Medicina que tendrá lugar en Londres en agosto será uno de los eventos internacionales de mayor envergadura en muchos años, dice The Times. Para indicar su importancia, basta con citar los nombres de los invitados y la cantidad de participantes. El comité organizador prevé la presencia de no menos de 5000 delegados médicos. Entre ellos, cerca de 2000, probablemente, provendrán de Gran Bretaña y de otros países de habla inglesa; alrededor de 1000 de Alemania, 1000 de Francia y 1000 de otros países. Para sus reuniones más importantes, el congreso sesionará durante tres días en el Albert Hall. Las reuniones de las distintas secciones serán muy numerosas, ya que habrá 26 secciones con sus subsecciones, la mayoría de las cuales se reunirán diariamente. Por lo tanto, necesariamente, los lugares de reunión estarán un tanto dispersos en varias partes de Londres" 24.

En 1881, esa ciudad ya había sido sede de la séptima edición de ese mismo congreso, que contó con la presencia de figuras como Louis Pasteur y Thomas Henry Huxley. Para esta edición, en cambio, no se esperaban quizás tantas figuras, pero sí una concurrencia mucho más masiva. Ya en junio de 1913, el British Medical Journal anunciaba algunas partes del programa. El jueves 7 de agosto, Joseph Babinski y Max Rothmann (el director de Berlín), debían inaugurar las sesiones de la sección de neuropatología, con una discusión sobre los síntomas del cerebelo y su significación. La intervención de Janet y Jung sobre el psicoanálisis estaba prevista para el viernes 8. Ese mismo día, paralelamente, Joseph Déjerine (el neurólogo franco-suizo) y Hugo Liepmann (un antiguo asistente de Carl Wernicke, de Berlín), animarían una charla sobre la afasia motora, la anartria y la apraxia, que sería continuada por Henri Claude y Constantin von Monakow, entre otros. A las 5 de la tarde, finalmente, en el Hospital Nacional Queen Square, se serviría un té, para el que también se esperaba la concurrencia de las damas ${ }^{25}$.

\section{La crítica centenaria de Janet: el papel de los recuerdos}




\section{traumáticos}

Según el relato de É. Roudinesco, en un día caluroso y húmedo, además de tormentoso, los organizadores invirtieron el orden de los oradores, dando primero la palabra a Janet, que en realidad debía presentar su informe después del de Jung ${ }^{26}$. El profesor francés comenzó explicitando su proyecto, en una muy larga alocución, que ocuparía más de 50 páginas de las actas (JANET, 1913). Frente al "psico-análisis" del vienés, cuyos discípulos presentaban "como un punto de vista nuevo" 27 , como una "revolución en la ciencia psicológica", no sin cierta ironía, Janet decía no poder exponer todos esos estudios, tan numerosos como variados. "Tampoco puedo aspirar a emprender aquí una discusión completa del psico-análisis, que no sólo toca todas las cuestiones de la psicología y de la psiquiatría, sino que aborda con la misma resolución todos los problemas de la gramática, de la lingüística, de la literatura, de las artes y de las religiones; me siento incapaz de seguir el psicoanálisis en todos esos niveles. Me propongo un objetivo mucho más modesto: quiero simplemente buscar, en algunos puntos determinados, lo que hay de característico y de nuevo en dichos estudios, para que así se encuentren los miembros del Congreso en condiciones de discutirlos y de elegir - con conocimiento de causa- entre la antigua y la nueva psicología" (Janet, 1914a, p. 1). Es decir que Janet, desde el inicio, situaba las doctrinas vienesas en el lugar de una supuesta novedad (cuya originalidad era necesario determinar), que se oponía a las teorías aceptadas por la comunidad médica. Al mismo tiempo, entre líneas, denunciaba justamente aquello que hacía al éxito mismo del psicoanálisis: el hecho de que trascendiera el marco restringido de las disciplinas psi para insertarse en debates intelectuales y culturales mucho más amplios, que no podían examinarse a la luz de los métodos clínicos.

En todo caso, las dos décadas transcurridas desde los primeros intercambios de Janet con Freud habían dejado su huella. Janet ya no podía referirse solamente a los primeros estudios publicados en Berlín y Viena, que remitían al método catártico (aunque se detuviera particularmente en ellos), sino que se vería obligado a tomar en cuenta el "psico-análisis" en sus distintas acepciones, como teoría sobre el funcionamiento psíquico, como método de exploración del inconsciente y como procedimiento terapéutico, pero también como movimiento institucional. No obstante, frente a esta polisemia de la creación freudiana, Janet no disponía aún de un término que le permitiera unificar toda su producción bajo un mismo sintagma. Por ese motivo, probablemente, en este debate promovió el antiguo "análisis psicológico" a esa categoría, lo cual le permitió contar con una apelación pasible de oponerse al psicoanálisis que pretendía impugnar. "Mis propios trabajos me dan, tal vez, el derecho de tratar 
de establecer esa distinción [entre la antigua y la nueva psicología]: El Sr. Freud ha destacado en sus primeras observaciones - con una amabilidad que le agradezco- mis investigaciones sobre la histeria. $Y$ el Sr. K. Jung [sic], en su informe sobre las teorías de la histeria, presentado en el Congreso de Amsterdam, ha tenido la bondad de señalar mi nombre entre los humildes precursores de la buena palabra ${ }^{28}$. Los estudios aludidos cortésmente por los mencionados autores no tenían nada de revolucionario: se esforzaban en aplicar el análisis psicológico - con sus antiguos métodos de observación y de inducción- a diversos síntomas patológicos. Puesto que de allí ha salido brillantemente el psico-análisis, es interesante constatar en qué difiere. Y mi trabajo tratará de echar luz sobre la diferencia entre el psicoanálisis y el análisis psicológico" (Janet, 1914a, 1-2). En estas pocas líneas Janet resumía el objetivo y los supuestos de su empresa, según veremos a continuación.

En primer lugar, es claro que Janet no aspiraba a que se le reconociera la paternidad del psicoanálisis. Pretendía más bien, una vez más, dejar sentado el carácter pionero de sus estudios y teorías sobre las neurosis y de sus procedimientos para abordarlas. Y daba por supuesto que el psicoanálisis no era más que una prolongación de esos estudios, teorías y procedimientos, que entonces unificaba bajo el rótulo de "análisis psicológico". De todos modos, para él, "pionero" no significaba "radicalmente original" ni "revolucionario". Janet consideraba sus propios trabajos como un paso más en la aplicación del método científico en el dominio de la clínica, basado principalmente en la formulación de hipótesis acotadas y comprobables, y en la paciente acumulación de observaciones a lo largo de los años. Por ese motivo, no podía dejar de atacar, una y otra vez, las pretensiones revolucionarias tan comunes entre los freudianos, a tal punto que parecían cimentar su identidad colectiva. En ese aspecto, no se trataba tanto de una disputa entre enunciados teóricos divergentes, como de una profunda diferencia sobre los modos de concebir la labor del científico y el avance de la ciencia.

En segundo lugar, por oposición al psicoanálisis, ante ese público tan selecto, Janet buscaba inscribir su análisis psicológico en toda una tradición médica y psicopatológica que incluía a Charcot pero también a Claude Bernard. Desde esa posición de insider, trataba a Freud como a un outsider, cuyas teorías, supuestamente originales, aún debían dar pruebas de cientificidad. Su línea argumental tendía a mostrar que lo que esas teorías tenían de verdadero no era nuevo, en la medida en que se basaba en el antiguo análisis psicológico. Y lo que tenían de nuevo, según veremos, no era verdadero, toda vez que se trataba de generalizaciones e hipótesis arriesgadas, que se alejaban imprudentemente del camino de la ciencia. En ese sentido, la opción entre la vieja y la nueva psicología no era tal, ya que existía una sola psicología: la científica. Y el trabajo de Janet sólo iba a tratar 
de mostrar hasta que punto la declamada revolución psicoanalítica quedaba por fuera del dominio de la ciencia psicológica. En otras palabras, la opción que presentaba a sus colegas era una falsa opción, un mero recurso retórico, que tendía a subrayar los méritos de su propia teoría, mientras demolía la teoría rival.

Con este fin, Janet dividió su exposición en tres partes. La primera, dedicada a los "recuerdos traumáticos", era una oportunidad para repasar, sobre todo, sus primeros trabajos sobre la histeria, destacando la deuda que Breuer y Freud tenían en ese respecto. "Tales investigaciones [las de Janet] siempre fueron presentadas como interpretaciones hipotéticas y parciales de trastornos neuropáticos. Los recuerdos traumáticos parecen desempeñar un rol esencial en cierto número de casos, pero es incontestable que pueden no tener más que una importancia restringida, o incluso pueden no tener ningún papel en otras observaciones" (JANET, 1914a, p 6) ${ }^{29}$. Es decir que los médicos vieneses se habían apoyado en estudios janetianos que, si bien subrayaban la relevancia de los recuerdos traumáticos, no pretendían tener la última palabra al respecto, ni aspiraban a generalizar su existencia a todos los casos de neurosis. Se sobreentendía que esa generalización corría por cuenta de Breuer y Freud, que confundían el "algunos" con el "todos" (del mismo modo en que transformaban hipótesis provisorias en ambiciosas teorías).

Respecto de la etiología de las neurosis, empero, el médico francés parecía hacer una concesión a los vieneses. Si bien hacía alusión a una multitud de causas posibles, para que los recuerdos devinieran patológicos, ya no hablaba en términos de "tendencia" sino de "estados". Pero no se refería a los estados hipnoides mencionados por Breuer. "Para que [el recuerdo] se vuelva peligroso hace falta que se encuentre con un estado mental muy particular, capaz de favorecer su desarrollo [...]. Traté de resumirlo con las expresiones angostamiento del campo de la conciencia, debilidad de la síntesis psicológica, descenso de la tensión psicológica, etc. El evento, para volverse peligroso y dejar un recuerdo traumático, debe coincidir con este estado de depresión mental" (JANET, 1914a, p. 6-7) ${ }^{30}$. Finalmente, más allá de las apariencias, lo que en 1893 se exponía en términos de "tendencia a la disociación" ahora se explicaba directamente a partir del estado resultante. Al mismo tiempo, en algunos casos, ese "estado depresivo" podía ser consecuencia del mismo hecho que había generado el recuerdo traumático. Pero en otros, podía ser el origen de una neurosis carente de recuerdos traumáticos.

"Ese era el balance de los estudios iniciados por el análisis psicológico sobre esta cuestión cuando aparecieron, en el mismo terreno, los trabajos del Sr. S. Freud y de sus numerosos alumnos, que, según parece, debían revolucionarlo todo. Tengo que confesar, con mucha vergüenza, que al principio no comprendí para nada la importancia de 
esa conmoción, y cándidamente consideré los primeros estudios de los Sres. Breuer y Freud como una de las más interesantes confirmaciones de los míos [...]. En efecto, esos autores mostraban, con ejemplos muy bien escogidos, que algunos trastornos eran consecuencia de "reminiscencias traumáticas", y sus observaciones constataba complacido- eran totalmente análogas a las mías. A lo sumo cambiaban algunas palabras en su descripción psicológica. Llamaban psico-análisis lo que yo llamaba análisis psicológico, nombraban como 'complejos' lo que yo había nombrado 'sistema psicológico'...; bautizaban con el nombre de 'catarsis' lo que yo designaba como una disociación de ideas fijas o como una desinfección moral [...]. Considerando esas primeras doctrinas y observaciones, es un tanto difícil comprender en qué difiere tanto el psicoanálisis del análisis psicológico y dónde reside el 'nuevo punto de vista' que aporta a la psiquiatría" (J ANET, 1914a, p. 9-10).

Curiosamente, en lo sucesivo, tratando de desentrañar "la novedad" del psicoanálisis, Janet iba a aferrarse casi exclusivamente a las concepciones freudianas decimonónicas (es decir, las menos alejadas de las suyas). Para períodos posteriores, en una época en que prácticamente no había textos de Freud traducidos al francés, iba a recurrir a lecturas de segunda y tercera mano, ya sea de sus discípulos (Jung, Maeder, Jones, Ferenczi, Sadger, Putnam), de sus comentaristas (Regis y Hesnard) y, sobre todo, de sus críticos (Ladame y Wells, particularmente). Era manifiesto que tenía dificultades con el alemán ${ }^{31}$, y que prefería manejarse con el inglés. Así, se refería a algunas traducciones de Brill y citaba numerosos artículos recientes del Journal of Abnormal Psychology, de Boston, que el año siguiente publicaría una traducción del texto completo del informe que estamos comentando (JANET, 1914d, 1914e). Esa revista, dirigida por Morton Prince, ilustraba muy bien la rápida penetración del psicoanálisis en la psiquiatría norteamericana, de tal suerte que Ernest Jones se había convertido en su director asistente, y que los primeros analistas bostonianos publicaban en sus páginas (como James Putnam, Isador Coriat, presente en el congreso de Londres, y John Donley). Todos ellos eran citados en la conferencia de Janet tanto o más que Freud. La otra gran revista de referencia era L'Encéphale, Journal de Neurologie et de Psychiatrie, dirigida por Joseph Déjerine y Henri Claude, quienes exponían en ese mismo momento en la sección de neurología ${ }^{32}$.

Janet tampoco encontraba en su método el aspecto novedoso del psicoanálisis. Por un lado, criticaba a Jung, quien alegaba que no se podía refutar el método analítico sin haberlo utilizado. Por el otro, citando a Brill, a Maeder y a Jones, consideraba que el análisis prolongado del enfermo, durante varios años, incluso, no tenía nada de original. En cuanto a la asociación libre, la abordaba de una manera singular, como un mero procedimiento técnico de 
observación, sin hacer alusión a su relación con los determinismos inconscientes. En todo caso, el test de asociación de palabras de Jung, que Janet vinculaba a los laboratorios de psicología, le parecía más interesante que el dispositivo freudiano, que descartaba sin mayores miramientos. "Los discípulos del Sr. Freud aconsejan ubicar simplemente al sujeto en un sillón, mientras que el médico se sitúa detrás de él y le dice que se deje llevar, que exprese en voz alta todos los pensamientos que espontáneamente le vengan a la mente. Me parece un procedimiento mediocre y un tanto ingenuo, ya que, a pesar de todo, el enfermo se siente vigilado y acomoda sus palabras más de lo que uno se imagina, buscando producir cierto efecto. Creo que no habría que recurrir a él a menos que no se disponga de otra posibilidad mejor. El enfermo debe ser observado muy a menudo, sin que lo sepa, cuando cree estar solo, como yo solía hacerlo (JANET, 1914a, p. 11-12).

En cuanto a la interpretación de los sueños, le restaba originalidad, diciendo que ya en 1851, Antoine Charma, entre otros, en su libro Du Sommeil, había mostrado que las pasiones y los deseos de los hombres se manifiestan más libremente en los sueños. "Hallándose el alma en profundo reposo y en calma descubre como en un fondo claro sus verdaderos afectos y anhelos, y, muy a menudo, lo que despiertos no osamos decir ni hacer se nos presenta en los sueños mientras dormimos" (CHARMA, 1851, p. 851, apud J ANET, 1914a, p. 16). No obstante, la crítica apuntaba al método de interpretación. En vez de provocar los sueños, o de registrarlos mientras se producían, Freud se limitaba a escuchar los relatos que los enfermos hacían de ellos horas o días después. Y luego, en lugar de criticar esos relatos, trataba de explicarlos por un principio general: el sueño implica la realización disfrazada de un deseo sexual reprimido. "Así, es bueno saber, para no perderse, que en los sueños una caverna o una casita significan siempre el órgano sexual femenino: la vulva; que una serpiente $o$ un bastón significan el órgano masculino: el pene. Y soñar que se camina por un bosque significa que uno se pierde en el vello púbico" (JANET, 1914, p. 18). Una vez más, como en el caso del recuerdo, para Janet, a partir de una hipótesis parcial (que algo se expresa en los sueños) el psicoanálisis llegaba a una generalización: que todo en el sueño expresa algo.

\section{El mecanismo patológico de los recuerdos traumáticos y su relación con la sexualidad}

La segunda parte de la exposición del filósofo-médico se refería al mecanismo patológico del recuerdo traumático. Según él, ya Charcot había puesto el énfasis en la sugestión como mecanismo psicológico. No obstante, él mismo había propuesto un mecanismo mucho más 
sencillo, el automatismo psicológico, que hacía posible la persistencia del sistema de hechos, imágenes y movimientos que constituían el recuerdo.

"Enriquecido de esta manera y fortalecido en medio de un conjunto de pensamientos debilitados por la depresión general, se realizaba por sí mismo, automáticamente, sin pasar por el intermediario de la idea y la sugestión, dando nacimiento a actos, actitudes, sufrimientos y delirios de distintas clases" (JANET, 1914a, p 20) ${ }^{33}$. Y esta concepción del mecanismo patológico, que desembocaba en la desagregación de la personalidad, a su juicio, ya había sido corroborada por sus amigos Morton Prince y Frédéric Paulhan, e incluso por psicoanalistas norteamericanos como Coriat y Donley, que utilizaban el concepto de automatismo, sin necesidad de referirse a expresiones como "conversión, transferencia y desplazamiento", que probablemente aludieran a los mismos hechos. "En realidad, pues, no se trata en esas expresiones del psico-análisis más que de cambios de palabras, sin mayor importancia" (p. 22).

No obstante, en este respecto, quedaba un problema que sí parecía prestarse a disidencias mayores: el de las "causas de la subconciencia", que Janet explicaba a partir de la desagregación producida por la depresión, y que los freudianos entendían como resultado de la represión. "Ellos se preocuparon, sobre todo, de descubrir el mecanismo por el que se producía esta subconciencia, la razón que hacía pasar tal o cual hecho del dominio de los fenómenos psicológicos concientes al grupo de los fenómenos subconscientes" (p. 26-27). Janet prestaba especial atención a la explicación sobre los pensamientos reprimidos que, por su carácter inadmisible, entraban en conflicto con la conciencia y, según él, se convertían en subconscientes. "La disociación ha sido el resultado de la represión. De esta manera, la conciencia no sufre más del conflicto, pero se angosta y se debilita" (p. 28). Y aquí cabe hacer dos aclaraciones. En ningún momento Janet se refiere al inconsciente en su sentido tópico, como un sistema con leyes propias, cuya existencia es anterior a la represión de representaciones particulares. Al mismo tiempo, para traducir el inconsciente freudiano a su propia terminología, se veía obligado a sustantivar lo que antes no había sido más que un adjetivo: además de mencionar actos y fenómenos subconscientes, comenzaba hablar de "la subconciencia" y de "lo subconsciente" ${ }^{34}$. Y se asombraba de que esa concepción, que él había elaborado entre 1886 y 1889, hubiera tenido "tan brillante destino". Por un lado, los espiritistas y los ocultistas habían hecho de ella "un principio maravilloso de conocimiento y de acción". Por otro lado, "la subconciencia se ha convertido para los psicoanalistas en el principio general y en la definición a priori de toda neurosis" (p. 35-36).

De todos modos, el médico francés habría aceptado de buen grado la noción de represión, pero a modo de hipótesis a comprobar. Según 
él, no bastaba con que esa explicación fuera posible para tenerla como exacta. Y otro tanto podía decirse sobre el problema de la transferencia. Si bien era sabido que muchos pacientes experimentaban hacia su médico "una afección particular, a veces extraña", ella podía obedecer a fenómenos psicológicos muy diversos, como "la sugestión, la abulia, la incapacidad de concluir por sí mismo, la necesidad de ser comprendido, la necesidad de ser dirigido y, sobre todo, la necesidad de ser excitado, tan importante en los deprimidos" (p. 34). El psicoanálisis pretendía explicar estos mismos hechos de manera mucho más simple: por la transferencia de las tendencias sexuales del complejo "hijos-padres" al complejo "sujetohipnotizador". "Una vez que se ha admitido que toda docilidad, sea cual fuere, es un símbolo de sentimientos eróticos, que en toda neurosis hay una transferencia inconsciente de algo, las cosas pueden explicarse de este modo (p. 34) ${ }^{35}$.

La misma crítica podía ser extendida a la explicación analítica de los lapsus, que más allá de la transferencia y la represión, podían obedecer a una multiplicidad de factores, como "perezas de la voluntad y de la atención, detenciones en el desarrollo de tal o cual tendencia cuya tensión es insuficiente, fenómenos de agotamiento, preocupaciones, hábitos, asociaciones de ideas, sugestiones, etc." ( $p$. 33-34). Una vez más, la discusión se planteaba entre un esquema monocausal, basado en la eficacia simbólica de complejos inconscientes, y una concepción pluricausal, que no tenía miramientos en contemplar factores heterogéneos, de diversos órdenes, en la medida en que se tratara de los agentes usualmente privilegiados en las tradiciones imperantes.

Si Janet no podía encontrar la diferencia entre análisis psicológico y psicoanálisis en la interpretación de los recuerdos traumáticos, en otros aspectos, esa diferencia no dejaba de parecerle "real" y "profunda". "No hay que buscarla en las observaciones y doctrinas, que son más o menos idénticas, sino en el método de estudio y en la concepción general que se hace de esas doctrinas" (p. 32). En ese punto, el simbolismo (y las interpretaciones a las que habilitaba) quedaba claramente por fuera de los cánones establecidos, tal como lo explicitaba el médico bostoniano Frederic Wells, en su "Critique of impure reason", que Janet glosaba: "La transformación de los hechos... puede ser enorme; y de ella resultar que un hecho cualquiera signifique lo que uno quiera. El autor agrega que se trata, para él, de una concepción ingenua del determinismo psicológico. Sobre todo, si no me equivoco, es una consecuencia de la confianza de los autores [psicoanalíticos] en un principio planteado de entrada como indiscutible; principio que no se trata de demostrar por los hechos, sino de aplicar a los hechos" (WELLS, 1912, apud JANET, 1914, p. 35). Así, una vez más, la distinción entre el psicoanálisis y el análisis psicológico se situaba menos en sus enunciados teóricos que 
en un plano epistemológico, en el que lo fundamental era el tipo de relación que se establecía entre las leyes, los principios y las hipótesis y su base empírica.

La tercera parte de la exposición de Janet se centraba, finalmente, en el problema de la sexualidad. Las operaciones de lectura eran similares a las empleadas en el resto del texto. Y a su vez no diferían mucho de las utilizadas dos décadas más temprano. Por un lado, se disolvía la originalidad del planteo de Freud, inscribiéndolo en una larga tradición que lo precedía (de Hipócrates a Charcot, pasando por Fillermay, Briquet, Axenfeld y Huchard). Por otra parte, se subrayaba que lo verdaderamente novedoso era la generalización de ideas que ya habían sido aceptadas por la comunidad médica. "Me parece difícil afirmar que el análisis psicológico se haya desentendido de este problema y que no haya estudiado las relaciones de las perturbaciones sexuales con las neurosis" (p. 98). Más aún, Janet admitía que tres cuartas partes de sus neurópatas padecían recuerdos penosos de contenido sexual. No obstante, era necesario determinar cuál era el lugar que esas perturbaciones ocupaban en la enfermedad en su conjunto. "Pero poco importa, estamos de acuerdo con el Sr. Freud en relacionar el inicio de la enfermedad con el evento sexual. Por otra parte, desde hace mucho tiempo, todos los autores estaban de acuerdo en admitir la existencia de hechos de este tipo" (p. 113). Dicho de otro modo: a la luz de las investigaciones existentes sobre el rol de la sexualidad en el las enfermedades mentales, resultaba ridículo situar en ese plano la supuesta revolución freudiana.

Pero la parte más virulenta de la crítica a las teorías analíticas sobre el rol de la sexualidad era la que se basaba en un trabajo de PaulLouis Ladame, un psiquiatra y neurólogo suizo que se había formado con Griesinger, en Wurzburgo, pero también en París, con Charcot. Durante los meses de enero y febrero, en L'Encéphale, había publicado un artículo (dividido en dos partes), "Névrose et sexualité", que Janet citaba abundantemente (casi tanto como el trabajo de Acher). No obstante, a diferencia de Acher, Ladame forzaba los textos que comentaba de una manera un tanto inusual, haciendo decir a sus autores cosas muy alejadas de las que realmente afirmaban. Y Janet se servía de esos pasajes como si se tratara de citas textuales. Así, por ejemplo, llegó a pensar que Freud aún daba un lugar preponderante a la neurosis de angustia, y consideraba que esta última se debía a un goce sexual incompleto, a un goce fallido causado, entre otras razones, por el mal hábito del coitus interruptus. Pero esta premisa, bastante fiel a la vieja concepción freudiana de las neurosis de angustia, según JanetLadame, el psicoanálisis también la hacía extensiva a las neuropsicosis de defensa, por lo que arribaba a las siguientes conclusiones: "Un coito normal y regular bastará siempre para curar 
todos los trastornos neuropáticos" 36. Así, supuestamente, Freud rogaba a los médicos que inventaran un preservativo capaz de prevenir las enfermedades y la concepción, para brindar un placer sin peligros. Más aún, Ladame hacía decir a Freud (el entrecomillado es de Janet): “Quien llegue a llenar esa laguna de nuestra técnica médica habrá conservado la salud y la dicha de innumerables personas" (LADAME, 1913b, p. 179, apud JANET, 1914a, p. 106). De este modo, con la ayuda de Ladame, Janet hacía que Freud Ilegara a generalizar justamente aquello que nunca había generalizado.

En general, en toda la conferencia, llama la atención el hecho de que su autor se refiera la mayor parte del tiempo a la etiología traumática de las neurosis, pasando por alto el viraje conceptual que implicó el abandono (o al menos la reformulación) de sus teorías decimonónicas. El lugar otorgado a las fantasías y las zonas erógenas (que aparece claramente en la bibliografía mencionada por Janet, aunque no en las partes que él elige citar) sería casi nulo, si no fuera por una alusión burlesca de Ladame. Éste último citaba a Kurt Mandel (en realidad, se trataba de Kurt Mendel, un psiquiatra berlinés, nada menos que el antiguo director del Neurologisches Zentralblatt), quien habría recreado la siguiente conversación satírica entre un padre y su pequeño: "Quizás no quisiste ir al inodoro antes de acostarte y rechazaste vaciar tu recto porque esperas obtener un goce voluptuoso de la defecación. Es por eso que te da placer retener tus excrementos" (LADAME, 1913b, p. 163, apud J ANET, 1914a, p. 101102). ¿Qué causas podrían haber llevado a Freud a urdir teorizaciones semejantes? Una vez más, Janet citaba a Ladame, quien, por su parte, se basaba en una explicación enunciada por Albert Friedländer en 1909: “Es que hay en Viena una atmósfera sexual especial, una suerte de genio, de demonio local que reina de manera epidémica sobre la población. En ese medio, fatalmente, un observador es llevado a otorgar una importancia excepcional a las cuestiones relativas a la sexualidad" (LADAME, 1913b, p. 160, apud J ANET, 1914a, p. 119) ${ }^{37}$.

Finalmente, el profesor francés terminaba de refutar a su colega vienés con la ayuda de un caso clínico. Se trataba de Newy, una mujer de treinta años, embarazada y recientemente casada, que era completamente indiferente a las solicitaciones de su esposo. Pero sus trastornos no se agotaban en la esfera sexual, sino que se extendían a toda su personalidad. Por eso, Janet sostenía que su abulia genital era una manifestación de su abulia general: "Nada es mío en este departamento... Pueden venir a llevarse todo, que no me quedaré con nada. No estoy atada a ningún objeto ni a ninguna persona" ( $p$. 116117). Según Janet, esos trastornos, de carácter general, eran anteriores al inicio de las relaciones sexuales con el marido, por lo que resultaba incorrecto atribuirles un origen genital. "Lo que prueba la exactitud de nuestra interpretación es que esta enferma se 
restableció poco a poco sin que nos preocupáramos en absoluto de modificar o de organizar mejor sus relaciones sexuales. Bastó con cuidados higiénicos, una dirección moral que disminuyó la dificultad para tomar decisiones, una educación gradual de su iniciativa [...]. Cuando un día, con mucha ayuda, logró organizar una cena en su casa, estuvo orgullosa, y su tensión aumentó lo suficiente como para poder amar a su marido, para obtener un goce completo" (p. 118). Este caso resume bien los malentendidos entre Janet y Freud sobre la sexualidad y la genitalidad, a la vez que muestra a las claras sus diferencias en la forma de concebir la cura y sus resortes.

Según su propio relato, este rol secundario que asignaba a los factores causales supuestamente evocados por Freud, ya le había valido a Janet una serie de críticas, empezando por la de Ernest Jones:

\footnotetext{
‘El Sr. Janet, dice, no psico-analizó a sus sujetos... Si lo hubiera hecho, necesariamente habría constatado que esas fallas de las funciones genitales son trastornos específicos que se deben a los primeros desarrollos de la vida sexual de los enfermos'. ¡Qué pena! El Sr. Jones tiene razón: yo no practiqué el psico-análisis. Es decir, yo no interpreté los dichos de los enfermos en el sentido de un dogma preestablecido. Y no podía hacerlo, justamente porque no creía en ese dogma, y porque trataba de constatar si era verdadero. Jones razona como los creyentes que no admiten la crítica de su religión (JONES, 1911, p. 98, apud JANET, 1914a, p. 118-119).
}

Y para completar esta afirmación categórica, citando una vez más a Ladame, Janet utilizaba una fórmula de Eugen Bleuler, que no tardaría en convertirse en un lugar común ( $y$ en un pilar) de todas las posturas adversas al psicoanálisis: “El análisis psicológico había constatado, a título de observación y de hipótesis, el rol considerable de la sexualidad en las neurosis; el psico-análisis transformó esta noción y la convirtió en el dogma del pansexualismo" (p. 120).

\section{La conclusión y el debate posterior a la crítica}

La conclusión de la exposición de Janet se titulaba "La filosofía y la psicología en medicina". Por primera vez, hacía alusión allí al movimiento analítico y a la futura fundación de la IPA, como un medio institucional para evitar la proliferación del "análisis salvaje". Extremando las comparaciones religiosas, mostraba su extrañeza ante la posibilidad de "la excomunión mayor de los herejes" ${ }^{38}$ :

De ahora en más, para evitar esas aplicaciones defectuosas del psico-análisis, el director de esta escuela va a formar una 
organización internacional que rehusará el título de miembro a todos los que no sean juzgados capaces de aplicar correctamente sus principios (J ANET, 1914a, p. 121).

Aunque, en realidad, la IPA ya hubiera sido creada tres años antes, es interesante constatar cómo Janet, por esa vía, reclamaba cierta "estabilización" del vocabulario analítico, particularmente en lo referido al significado atribuido a la sexualidad. De hecho, para él, un analista que había aconsejado a una paciente separada y deprimida que volviera inmediatamente con su marido o se buscara un amante, no había hecho más que aplicar muy correctamente las doctrinas de su maestro sobre las consecuencias de la insatisfacción sexual. $O$ al menos las había interpretado de la misma manera en que Janet las entendía. Freud, en cambio, lo había criticado (en un artículo de 1910, comentado por Acher), porque pensaba que este discípulo había restringido el sentido de la vida sexual, limitándolo a las funciones somáticas, mientras que el psicoanálisis tomaba ese término en un sentido mucho más amplio (FREUD, 1910; ACHER, 1911 , p. 425, apud JANET, 1914a, p. 121). Quizás podría decirse que Janet, valiéndose de ese discípulo, se aferraba a una concepción que había sido la de Freud (sobre una afección particular, en un momento puntual), a la vez que ignoraba (¿o desdeñaba?) las profundas modificaciones que se habían producido en la teoría psicoanalítica después del cambio de siglo.

Lo cierto es que buena parte de las conclusiones giraba en torno de este problema. El médico filósofo, a la vez que criticaba con firmeza la imprecisión del lenguaje analítico, parecía incapacitado para comprender la lógica que lo articulaba. Así, seguía a Putnam, Maeder y J ones para tratar de entender el sentido metafórico que ellos daban a la "tendencia sexual". Putnam afirmaba que la civilización consistía en la "transformación y sublimación" del instinto sexual (Putnam, 1910, p. 375, apud JANET, 1914a, p. 121). Maeder, por su parte, aconsejaba tomar la palabra sexual como los poetas, "cuando dicen que el hambre y el amor manejan el mundo" (Maeder, 1912, apud JANET, 1914a, p. 121-122). En cuanto a Jones, explicaba que el instinto sexual, en Freud, tenía el mismo valor que la "voluntad de poder" en Schopenhauer o que el "élan vital" en Bergson (JONES, 1913, p. xi, apud JANET, 1914a, p. 122). De todos modos, Janet, siguiendo a Ladame, se unía a otros autores (como Otto Hinrichsen) para protestar "contra esa extensión indefinida de la frase 'tendencia sexual'" y "contra esos abusos de lenguaje". Es que, como buen evolucionista, no podía tolerar que "la supuesta sublimación" terminara confundiendo "las tendencias más elevadas del espíritu humano" con los instintos "comunes a todos los animales". "Esos ejercicios oratorios, en realidad, son muy fáciles; con un poco de interpretación, de desplazamiento, de dramatización, de elaboración, 
y con muy poco espíritu crítico, cualquier cosa puede generalizarse de ese modo, haciendo que todo tenga que ver con todo. Ayer, todas las neurosis eran sugestiones; hoy son todas trastornos sexuales. Mañana, todas ellas serán perturbaciones del sentido moral o del sentido artístico" (p. 122-123).

Si bien el médico francés reconocía el interés del estudio de la relación entre los instintos sexuales, los sentimientos amorosos, las artes, la poesía y la religión, lo inscribía en el dominio de la filosofía general, por no decir en el de la metafísica (cuyo lugar estaba en los "templa serena" de los congresos, pero no en las salas de hospital ni en las camas de los enfermos). Llegaba entonces a la siguiente conclusión: “El psico-análisis es, antes que nada, una filosofía; interesante quizás, si se presenta a los filósofos... Lamentablemente, el psico-análisis quiere ser, al mismo tiempo, una ciencia médica, con la pretensión de aplicarse al diagnóstico y al tratamiento de los enfermos. He aquí el verdadero origen de todas las dificultades y malentendidos que hemos encontrado en su estudio" (p. 129). Aun así, Janet estaba dispuesto a admitir que la ciencia, de tanto en tanto, necesitaba renovar su vocabulario a partir de especulaciones filosóficas. Pero en ese caso, debía tratarse de ideas que suscitaran consenso, que formaran parte del pensamiento de una época, y no de "concepciones filosóficas imaginadas a voluntad, que los filósofos no tienen la menor gana de adoptar" (p. 129). En resumidas cuentas, el psicoanálisis era una filosofía que ni siquiera gozaba del reconocimiento de los filósofos...

Pese a lo anterior, Janet no ponía en duda las curaciones logradas a través del psicoanálisis, aunque las situaba en una serie muy poco conforme a los cánones científicos: "El templo de Esculapio ha curado miles de enfermos, [la virgen de] Lourdes ha curado miles de enfermos, el magnetismo animal ha curado miles de enfermos, la "Christian Science" ha curado miles de enfermos y el psico-análisis ha curado miles de enfermos [...]. Es por eso que no es muy útil exponer ante los médicos los millares de curaciones obtenidas; y es por eso que, sobre todo, es necesario indicarles con mucha precisión el mecanismo fisiológico y psicológico de esas curaciones, así como las razones que hacen suponer que tal o cual práctica, bien definida, ha sido terapéutica [...]. No alcanza con decirnos que un enfermo se ha curado luego de sumergirse en una piscina o después de relatar en detalle sus primeras masturbaciones. Aún es necesario que se nos haga comprender el determinismo que vincula esos fenómenos, probando que fue el baño o el relato lo que determinó la curación" ( $p$. 124-125). Y es claro que, para Janet, aunque la explicación basada en la eficacia de ideas ajenas a la conciencia fuera posible, eso no la hacía en absoluto necesaria.

En cuanto a las formas de tratamiento, básicamente, según Janet, el psicoanálisis proponía dos: la práctica del coito normal (para evitar la 
frustración sexual que conducía a la angustia) y la búsqueda del recuerdo traumático (que suprimía la eficacia de la idea reprimida). La primera forma quedaba invalidada por el ejemplo de las parejas estériles que, perfectamente satisfechas en el plano sexual (al no necesitar practicar el coito reservado), de todos modos desarrollaban psiconeurosis. La segunda era refutada más sencillamente: ya la había inventado el propio Janet, pero a modo de "preámbulo". Lo realmente complicado no era descubrir el trauma, sino ayudar al sujeto a adaptarse a la situación dificultosa que le dio origen, para poder realmente liquidarla. Pero esto Janet ya lo había enunciado en 1893, cuando daba la bienvenida a los estudios de Breuer y Freud. En 1913, para concluir su informe, se trataba más bien de despedirlos con la misma politesse. "Muy a menudo, una de esas doctrinas ambiciosas, que pretenden explicarlo todo con una sola palabra, provoca un gran movimiento de investigación. La tesis orgullosa y pueril no tarda en desaparecer, pero queda una cantidad de observaciones preciosas, que ella ha ayudado a realizar [...]. Lo mismo sucede, si no me equivoco, con los innumerables estudios de Freud y sus discípulos [...]. Ya se olvidarán las generalizaciones exageradas y los simbolismos aventurados que hoy parecen caracterizar esos estudios, separándolos de los otros trabajos científicos. No recordaremos más que una sola cosa: que el psicoanálisis ha prestado grandes servicios al análisis psicológico.

Luego del informe de Janet, fue el turno de Carl Gustav Jung, quien realizó el suyo en inglés, y empezó criticando a su predecesor en el uso de la palabra. "Lamentablemente, ocurre a menudo que la gente se siente capacitada para juzgar el psicoanálisis, cuando ni siquiera es capaz de leer en alemán". No obstante, más allá de este comienzo incisivo, según el relato de Ellenberger, el resumen del psicoanálisis que presentó el suizo terminó acercándose más a las ideas de Janet que a las del propio Freud. "Propongo liberar la teoría psicoanalítica del punto de partida puramente sexual. En su lugar, me gustaría introducir un punto de vista energético en la psicología de las neurosis" (ELLENBERGER, 1976, p. 921) ${ }^{39}$. Luego comparó la libido con el élan vital bergsoniano, y la neurosis con un acto de adaptación que produce un derroche de energía que permite el reemplazo de las funciones superiores por las inferiores ${ }^{40}$. Un resumen anónimo de este informe, publicado en 1914 (en el último número del Zentralblatt für Psychoanalyse und Psychotherapie, la revista fundada por Freud en 1910), nos brinda más detalles al respecto:

En las diferentes manifestaciones del desarrollo de la sexualidad infantil, y de las fantasías correspondientes, no veo la etiología real de una neurosis. El hecho de que ellas aparezcan exageradas o destacadas en una neurosis es una consecuencia de la acumulación de energía o de libido. Las alteraciones psíquicas en la neurosis y la neurosis misma 
tienen que ser considerados como un acto exitoso de adaptación. Esta formulación puede reconciliar ciertas opiniones de Janet y de Freud, según las cuales una neurosis es considerada - en cierto modo- como un intento de autocuración [...]. Mi comprensión diversa de la teoría de las neurosis no altera el procedimiento psicoanalítico. La técnica sigue siendo la misma. Ya no creemos que mediante este procedimiento pongamos al descubierto las raíces más profundas de las enfermedades. Pero sí debemos sacar a la luz las fantasías del enfermo, porque la energía que precisa para su curación, es decir, para su adaptación, está ligada a fantasías sexuales. Mediante el psicoanálisis vamos a reestablecer la conexión entre la conciencia y la libido inconsciente. De este modo, vamos a poner la libido inconsciente al servicio de una intención consciente. Este procedimiento basta para hacer reutilizable la energía bloqueada, que se precisa para cumplir con las exigencias de la vida. En este aspecto, me parece que un psicoanálisis bien aplicado implica una tarea de alta moralidad y gran valor educativo (JUNG, 1914, p. 316).

En este aparente intento de conciliación entre Freud y Janet, realizado por quien supuestamente encarnaba la defensa del psicoanálisis, podría decirse que, el que más perdía, era el maestro vienés. En efecto, por un lado, Jung restaba importancia a la sexualidad infantil y a las fantasías, que Janet, a su vez, había menospreciado (aunque para Freud tuvieran un rol preponderante). Por el otro, explicaba la neurosis en términos de una energía desexualizada, ligada a problemas adaptativos, tal como Janet lo venía haciendo claramente desde 1889. En definitiva, ¿qué mejor representante de la posición del francés que un psicoanalista que, prescindiendo de los factores sexuales, consideraba la etiología de las neurosis como un problema ligado a la energía necesaria para la adaptación? En realidad, más que una articulación entre psicoanálisis y análisis psicológico, la intervención de Jung parecía formalizar un acercamiento con su viejo maestro francés, en un momento en el que estaba a punto de alejarse definitivamente de su referente vienés. Y la exposición de Jung no hacía más que poner de manifiesto los puntos teóricos nodales que, más allá de cuestiones personales, habrían de precipitar esa separación. No es casual que, en lo sucesivo, Jung y Janet se convirtieran en dos de los mayores referentes de las psicoterapias no freudianas. Al mismo tiempo, a partir de ese mismo año, el psicoanálisis de Freud y el "análisis psicológico" de Janet deberían convivir con la psicología analítica junguiana, tres apelaciones que no sólo tenían una gran homofonía, sino que remitían a una historia de progresiva diferenciación entre sus autores ${ }^{41}$.

En la discusión posterior a la presentación de los informes de Janet y de Jung, la repartición del uso de la palabra fue equitativa. Además 
de los conferencistas, intervinieron cuatro psicoanalistas (que obviamente defendieron el psicoanálisis), cuatro psiquiatras (críticos en diverso grado) y el coordinador de la sección (más afín al primer grupo que al segundo). Es decir que se trató de una discusión pareja, en la que el presidente de la mesa terminó inclinando levemente la balanza. Sin embargo, Ellenberger difiere un poco en los cálculos, sin tener en cuenta la filiación de los oradores y sin citar sus fuentes:

\begin{abstract}
Participaron nueve personas, cinco de las cuales se mostraron favorables a Freud, tres contrarias y una neutral [...]. Todos los relatos sobre esta discusión confirman su carácter tormentoso (ELLENBERGER, 1976, p. 921-922).
\end{abstract}

Roudinesco, por su parte, basándose en Ellenberger, acentúa aún más las distancias:

\begin{abstract}
En la discusión, nadie responde [a Jung], pero cinco participantes de ocho se dicen favorables al psicoanálisis, contra Janet. Dos le son francamente hostiles, y sólo uno permanece neutral [...]. En cuanto a Janet [el día siguiente], está en el colmo de la furia, se deja llevar, pierde su timidez legendaria, insulta a sus colegas y se ve en la obligación de pedir disculpas (ROUDINESCO, 1994, p. 256).
\end{abstract}

En realidad, lo que surge de la retranscripción de las actas del congreso (la única fuente de que disponemos), pinta un panorama bastante menos belicoso ${ }^{42}$. La primera intervención (y la más breve) fue la de Jones, quien se lamentó de que "el profesor Janet no hubiera logrado presentar un resumen más objetivo y preciso del psicoanálisis". A lo cual agregaba, punzante, que "para estar en condiciones de criticar una nueva teoría, primero es necesario comprenderla" (DISCUSSION, 2004, p. 114). Isador Coriat, el analista bostoniano que Janet tanto había citado, empezaba admitiendo que, en el pasado, se había opuesto al psicoanálisis. "Pero la experiencia me ha demostrado la validez integral de la teoría psicoanalítica, tanto desde el punto de vista psicológico como terapéutico". Y realizaba una precisión importante sobre la etiología de las neurosis:

Se trata menos de un traumatismo sexual que del desarrollo, durante la infancia, de un complejo de Edipo o de Electra, y de la resistencia más o menos lograda a ese complejo (DISCUSSION, 2004, p. 115).

En tercer lugar, tomó la palabra David Forsyth, uno de los analistas que, junto con Jones, dos meses después, iba a fundar la London Psychoanalytic Society. Por un lado, al igual que Coriat, ponía el énfasis en la importancia de la sexualidad infantil, que había implicado una laguna en el informe de Janet. Sin embargo, lo hacía 
desde una perspectiva singular, poniendo de relieve la educación moral de los niños, "la cuestión más importante de nuestra época, cuyo estudio científico no puede emprenderse por una vía mejor que la del psicoanálisis". Por otro lado, acercándose a Jung, afirmaba que no era necesario "llevar la investigación hasta la infancia en todos los casos de psiconeurosis" (p. 115).

En cuanto a Thomas Williams, el psiquiatra de Washington supuestamente "neutral", si bien reconocía que la investigación psicoanalítica de las enfermedades implicaba un avance importante respecto de su mera descripción, consideraba a algunos de los participantes que lo habían precedido como "deplorablemente dogmáticos". Ponía en duda que un complejo pudiera perturbar la vida mental manteniéndose inconsciente, negaba la posibilidad de curación analítica de los "hábitos mentales", refutaba el concepto de transferencia y señalaba que en el procedimiento analítico se ocultaba una "sugestión implícita". Respecto del papel de la sexualidad, compartía claramente la posición de Janet. Admitía que ella era la fuente principal de las psiconeurosis. No obstante, "querer hacer de eso algo universal, convirtiendo la libido en un sinónimo de la fuerza vital, es vaciar a los términos de su sentido" (p. 116) ${ }^{43}$. En cuanto a Lothar Ritter von Frankl-Hochwart, un neurólogo vienés (hijo de un famoso poeta y discípulo de Meynert), seguía la línea de su maestro, al sostener que el freudismo no había expuesto casos determinantes que no hubieran podido ser curados por otros médicos. Tampoco había aportado estadísticas precisas que mostraran la proporción de éxitos y fracasos respecto del total de pacientes analizados. Peor aún, "una parte de los psicoanalistas no son médicos sino pacientes. Estas personas, a menudo, producen fatalidades" ( $p .117$ ).

La sexta intervención correspondió a otro psicoanalista londinense, David Eder, quien también iba a participar, en el mes de octubre, en la fundación de la London Psychoanalytic Society ${ }^{44}$. Planteó que toda teoría atravesaba tres fases. Al principio, era considerada absurda, "una herejía". Luego, se le reconocían algunos aciertos. Finalmente, se tenía la impresión de que todo lo que decía ya era sabido desde hacía mucho tiempo. Para él, el informe de Janet sobre el psicoanálisis invocaba simultáneamente esos tres niveles. “Por momentos, le parece que se trata de su propio método de análisis psicológico ${ }^{45}$. En otros momentos, le parece absurdo. $Y$ finalmente, cree que contiene algunas cosas perspicaces" ( $p .117$ ). No obstante, lo que para él resultaba más grave era que aún se atribuyera a los psicoanalistas la idea de que el recuerdo traumático era la causa de la neurosis. "Aunque afirme que esos traumas existen, ya hace 15 años que Freud no les atribuye un rol causal. Freud y Jung están de acuerdo sobre el hecho de que la sexualidad infantil siempre debe estar en juego" (p. 117-118).

Luego fue el turno de los psiquiatras James Walsh, de Nueva York y 
Edgar Bérillon, de París. Para los estándares norteamericanos, Walsh era un caso raro. Era a la vez doctor en medicina y filosofía, además de profesor de psicología fisiológica y miembro vitalicio de la New York Historical Society. Acordaba plenamente con Janet en el hecho de inscribir el psicoanálisis en la larga línea que iba desde el mesmerismo hasta el "eddysmo" (es decir, la Christian Science). Para él, todas esas terapias habían sido peligrosas, en la medida en que debilitaban la voluntad y hacían a los pacientes dependientes. Con el psicoanálisis, específicamente, el peligro residía en la sobreestimación de la sexualidad: "No hay ninguna duda de que los neuróticos deben reducir su sexualidad más que aumentarla" (p. 118). En cuanto a Bérillon, se trataba de un neurólogo francés especializado en hipnotismo, además de un tradicionalista exacerbado ${ }^{46}$. En su alocución establecía seis condiciones fundamentales que el psicoanálisis debía cumplir "para entrar en el dominio científico y dejar de ser considerado como una terapéutica puramente empírica" (p. 118). A su juicio, lamentablemente, las prácticas freudianas no cumplían con ninguna de esas reglas; especialmente la quinta: "No entrar en oposición con las tendencias sociales, las ideas religiosas, los principios morales. Las cuestiones relativas a la sexualidad no deberían ser abordadas más que en presencia de testigos, con la garantía y bajo el control de la familia" (p. 118-119).

Finalmente, antes de dar su derecho a réplica a los dos conferencistas, hizo uso de la palabra Sir Georges Savage, el coordinador de la sección, un eminente psiquiatra británico que había sido elevado al rango de caballero el año anterior ${ }^{47}$. Savage elogió la elocuencia y el entusiasmo de Janet. No obstante, previno a la audiencia sobre la necesidad de "no dejarse perder" por esa capacidad oratoria, utilizando la metáfora de Ulises y Ajax. En su disputa por la armadura de Aquiles, gracias a su elocuencia, Ulises había logrado vencer a Ajax, que era más fuerte. En este caso, ¿eso quería decir que la fuerza de los psicoanalistas no debía ceder ante la elocuencia janetiana? No queda del todo claro. En todo caso, su simpatía por los argumentos freudianos sí era manifiesta, por más que la expresara en términos janetianos. "Desde el comienzo mismo de mis enseñanzas he subrayado que el espíritu, como un edificio, descansa sobre cimientos que no por ser invisibles dejan de asegurar la estabilidad de toda la estructura. Todo lo que pueda permitirnos reconstruir el desarrollo del subconsciente deberá utilizarse para elucidar los trastornos mentales y sus causas, lo cual también nos permitirá, ciertamente, tratarlos más racionalmente [...]. Nada es más útil para la humanidad que la crítica prudente; estemos atentos, sin rechazar lo que no comprendemos, y estemos listos para aceptar lo que está probado" (p. 119).

En sus respuestas, tanto Janet como Jung fueron muy breves. Janet se mostró complacido de constatar que muchos oradores habían 
podido "exponer y defender" la obra del profesor de Viena mejor que él. "Los estudios relacionados con el psico-análisis son innombrables. Al lado de los estudios sobre los sentimientos sexuales, también hay que hacer un gran lugar a los trabajos sobre el desarrollo del pensamiento en la infancia ${ }^{48}$. Sería enojoso que nos limitáramos a una discusión y a una crítica. Para terminar, quiero expresar toda mi admiración por la obra considerable del Sr. Freud y de sus discípulos" (p. 119-120). Jung, por su parte, destacaba que "en los informes no se alegó ninguna razón contra el psicoanálisis que no pueda responderse o que no pueda explicarse fácilmente". "Me quedo con una hermosa impresión de esta discusión" (p. 120).

\section{El múltiple impacto de la crítica de J anet}

Más allá de alegoría de la armadura de Aquiles, evocada por Sir Savage, considerando lo desarrollado en el apartado anterior, la imagen bélica que construye el relato de E. Roudinesco parece un tanto forzada. “El 'combate de Bouvines' de 1913 marca la derrota de la flor de lis. La apuesta del filósofo está perdida. El contraataque del hombre de Zurich es mordaz, y el del galés, despiadado. Jung sube a la tribuna $y$, orgulloso de su sintaxis inglesa, recuerda a Janet su ignorancia de la lengua alemana. Le cuestiona el derecho de hablar del psicoanálisis y le propina una dolorosa herida narcisística [...]. Finalmente, Jones avanza en primera línea, $y$, en medio de la confusión general, blande la lanza y la oriflama para aniquilar a un adversario ya malherido. Janet es acusado de utilizar sus dotes de comediante para burlarse de la obra freudiana. Es calificado de envidioso y celoso. Es denunciado por su ignorancia del psicoanálisis, sus pretensiones absurdas y su falta de lealtad. El duelo es breve, brutal e incendiario. Al día siguiente de la batalla, en su resumen de los acontecimientos, el Times olvida mencionar la intervención del galés. Pero en sus Memorias, él se cantará a sí mismo sus alabanzas" (ROUDINESCO, 1994, p. 256-257).

Siguiendo de cerca sus dos intervenciones, excepto por alguna ironía, salta a la vista que Jung estuvo lejos de pelearse con Janet. En cuanto a Jones, si el Times se olvidó de él, probablemente se debió a que la alocución que realizó, más allá de sus relatos posteriores, pasó prácticamente inadvertida. No sólo no le dio a Janet la estocada final, sino que no hubo ningún duelo entre ellos. En realidad, el futuro biógrafo de Freud fue el primero en hablar y el que menos cosas dijo. Por otra parte, según veremos a continuación, parafraseando a Corneille y a Zorrilla, los muertos que Jones mataba, gozaban de buena salud... En todo caso, las múltiples acciones de Jones luego del congreso sí parecen haber tenido un peso importante en el establecimiento de la versión histórica según la cual el congreso de 
Londres habría implicado una contundente victoria del bando psicoanalítico.

En primer lugar, inmediatamente después del evento (el mismo 8 de agosto), envió una carta a Freud en la que le relataba los hechos de una manera particularmente sesgada, tanto por sus exageraciones como por sus omisiones. "Estoy particularmente contento con los acontecimientos y la recepción que hemos tenido en Londres, desde todo punto de vista [...]. El debate sobre $\psi \mathrm{a}$ [psicoanálisis] de esta mañana fue ciertamente un gran éxito. Aquí le envío las Sammelreferate [ponencias conjuntas] de Janet y de Jung sin agregar nada sobre ellas, salvo que fue una suerte que el trabajo de Janet haya sido tan estúpido como para exponerse a los ataques de una manera tan ingenua. Se me pidió que abriera la discusión, lo cual resultó una tarea fácil, ya que me encontraba en excelente forma para hablar. Señalé que el trabajo de Janet estaba lleno de representaciones erróneas y falsedades, lo cual fue fácil de probar [...]. Otros también criticaron a Janet [...]. Jung desempeñó un papel tranquilo, dijo cortésmente algunas generalidades y se mantuvo en segundo plano. Asistieron pocos alemanes, si es que fue alguno. La mayoría eran ingleses, lo que para él, al hablar en alemán, fue una desventaja ${ }^{49}$. Como resultado, podría decirse que Janet está destruido, y que el debate, al menos, no hizo ningún daño en Inglaterra. La impresión general, ciertamente, nos fue favorable. También estoy muy complacido con la forma en que fui recibido, und denke jetzt, die Sache wird schon in England gehen" (JONES, 1913, p. 216-127) ${ }^{50}$.

Ante semejantes noticias, Freud no tardó en responder, dos días más tarde, desde Marienbad, de manera tan breve como entusiasta: "Mi querido Jones, no puedo decirle lo complacido que estoy por su informe sobre el Congreso, y de que usted haya derrotado a Janet ante los ojos de sus compatriotas [los de Jones]. El interés del $\Psi \mathrm{A}, \mathrm{y}$ el de su propia persona, en Inglaterra, son idénticos. Ahora confío en que usted va a schmieden das Eisen solange es warm ist" (FREUD, 1913 , p. 217) ${ }^{51}$. En realidad, más allá del elogio, se trataba de una invitación a la acción - que el nuevo lugarteniente no tardaría en aceptar-, en un momento de máxima inestabilidad para el movimiento. De hecho, la ruptura entre junguianos y freudianos se consumó tres semanas más tarde, en el Congreso de Munich. Y un mes después, sin pérdida de tiempo, Jones iba a iba a fundar la London Psychoanalytic Society, mientras el hierro "aún estaba caliente". Por otra parte, envió al Zeitschrift un comentario sobre el informe de Janet, que recién se iba a publicar tres años después, con agregados al pie de Sigmund Freud (JONES, 1916) 52. Incluso, muchos años después, en su biografía de Freud, resumiría lo sucedido de la siguiente manera: 
En la primera semana de agosto, en el Congreso Internacional de Medicina, hubo un duelo entre Janet y yo, que puso fin a las pretensiones de aquél. Janet sostenía haber sido el creador del psicoanálisis, y que Freud no había hecho más que estropearlo posteriormente (JONES, 1954, p. 325).

Pueden reconocerse ahí los elementos iniciales de una leyenda que habría de perdurar y que este trabajo intenta cuestionar.

Más allá de las metáforas bélicas (de las derrotas contundentes y de las victorias auto-atribuidas), lo cierto es que la crítica de Janet iba a tener una difusión poco común. Luego de su publicación en las actas del congreso, en 1913, entre 1914 y 1915 iba a ser reproducida en cuatro idiomas diferentes, en sitios y en modos inesperados. Por ejemplo, llama la atención que, en primer lugar, haya sido publicada en alemán, en Viena, en el que iba a ser el último número del Zentralblatt für Psychoanalyse und Psychotherapie, que aún era el órgano oficial de la IPA. Las razones por las que se la publicaba, explicitadas en una nota al pie del comité de redacción, eran aún más curiosas:

Debido al hecho de que el conocido discurso de Janet sobre Freud aparece mutilado y desfigurado en la mayoría de los informes, hemos decidido publicar la conferencia según el informe original. Se hará evidente para nuestros lectores que Janet no niega los grandes méritos de Freud y reconoce su importancia en un mayor grado que lo que nos hicieron creer aquellos informes que destacaban algunos aspectos de ese discurso y suprimían otros igualmente importantes" (J ANET, 1914 b, p. 309) ${ }^{53}$.

Pero lo verdaderamente llamativo es que, al mismo tiempo que se criticaban las versiones fragmentarias que habían circulado hasta entonces, sin ningún tipo de aclaración para el lector, sólo se publicaban las conclusiones, lo cual daba a suponer que se trataba de la totalidad del informe. Por otra parte, las razones invocadas para reproducir ese trabajo no aludían a la pobreza de los argumentos de Janet sino a su magnanimidad para con las doctrinas freudianas. Es decir que difícilmente se esperara ese tipo de reconocimiento de parte de alguien a quien se consideraba claramente derrotado o herido de muerte.

El segundo lugar en que se publicó la famosa crítica, directamente en francés, era mucho más esperable: el Journal de Psychologie Normale et Pathologique, que el mismo Janet había co-fundado en 1904, con Georges Dumas. El texto del informe se transcribía en su totalidad, aunque no aparecía la intervención de Jung ni la discusión posterior (JANET, 1914a). Todo indica que el debate sobre el psicoanálisis se había transformado en un tema de actualidad. A tal punto que, 
todavía en 1914, en el mes de junio, tuvo lugar la reunión anual de la "Sociedad de psicoterapia, de hipnología y de psicología", bajo la presidencia de Pierre Janet. El objeto de las diferentes ponencias era "El valor del psico-análisis de Freud". Aparentemente, las críticas fueron tan unánimes, que el profesor del Collège de France tuvo que intervenir. "No querría que nos limitásemos a estas discusiones; no me parece conveniente que, en una reunión de médicos franceses en la que se han puesto en el orden del día los trabajos del Sr. Freud, no se presenten más que críticas en este respecto. No sería cortés de nuestra parte y, puedo asegurarles, no sería justo" (J ANET, 1915, p. 82). Henri Ellenberger cuenta el episodio de la siguiente manera: "Cuando el propio Freud fue duramente atacado en la reunión de la Sociedad de Psicoterapia, el 16 de junio de 1914, [Janet] lo defendió; valiente acto, considerando el creciente sentimiento anti-alemán que se extendía por Francia" (ELLENBERGER, 1976, p. 394).

Si bien es cierto que en vísperas de la Gran Guerra todo aquello que proviniera de Austria o Alemania generaba cada vez más resquemor, no parece que la actitud de Janet hubiera sido tan valiente, ni que implicara un cambio de posición radical respecto de Freud. Simplemente había repetido de manera sintética lo mismo que había dicho en Londres, con similar politesse: el psicoanálisis, pese a sus errores, sus exageraciones y sus generalizaciones injustificadas, había aportado estudios valiosos. Aunque, en un punto, quizás podría afirmarse que Janet comenzaba a admitir que había allí algo diferente de sus propios descubrimientos:

[Los estudios analíticos] han aportado contribuciones notables al análisis del estado mental de los neurópatas y al conocimiento de la psicología infantil. ¿No están ustedes asombrados como yo de la renovación que han provocado en las investigaciones sobre la psicología de los fenómenos sexuales de la humanidad? Una especie de falsa vergüenza impedía a menudo analizar en detalle esos fenómenos. Los trabajos de la escuela del Sr. Freud se han agregado a los libros tan importantes del Sr. M. Havelock Ellis, en Inglaterra, para mostrar el interés capital de esos estudios, y para motivarnos a elaborar una psicología de la sexualidad. Sepamos reconocer todos sus méritos [...] (J ANET, 1915b, p. 82).

Aunque Janet no llegara al punto de reconocer el valor que el psicoanálisis acordaba a la sexualidad infantil, al menos admitía sus aportes a los estudios sobre la sexualidad, por un lado, y sobre la psicología infantil, por el otro. Sea como fuere, eso lo hacía ir un paso más allá de las críticas sobre el pansexualismo, que igualmente iban a seguir estando presentes. Esta mezcla ambigua, entre el reconocimiento y la crítica, iba a dejar su huella en las concepciones de los primeros freudianos franceses, como Angelo Hesnard y 
Édouard Pichon. Según bien señala Roudinesco, ellos iban a corregir los principios esenciales del freudismo con un "janetismo de ocasión", reemplazando el inconsciente por una suerte de conciencia neocartesiana y exaltando el pensamiento latino por sobre los "vicios" germánicos (ROUDINESCO, 1994). Así, por ejemplo, en 1927, al comentar un libro de Janet en la Revue française de Psychanalyse, Hesnard podía sostener que "no es necesario recurrir al Psicoanálisis para admitir el descubrimiento de Freud; es decir, el origen sexual específico de las neurosis. El análisis psicológico puede bastar a un observador dotado de intuición psicológica y desprovisto de prejuicios filosóficos" (HESNARD, 1927, p. 637). Dos décadas más tarde, incluso, Daniel Lagache iba a fundar una psicología clínica de filiación psicoanalítica, basada en parte en la psicología de la conducta de Janet, al tiempo que, al igual que este último, definiría la enfermedad en términos adaptativos (LAGACHE, 1949; DAGFAL, 2002; 2011).

El tercer lugar en que se publicó la crítica de Janet es bastante inesperado, aunque no tanto si se considera el lugar que le cupo al pensamiento francés en la historia de la psiquiatría del país en cuestión. Se trata de la Argentina, más precisamente, de los Archivos de Ciencias de la Educación de la Facultad de Ciencias de la Educación de la Universidad Nacional de La Plata (UNLP), cuyo primer número acababa de editarse bajo la dirección de Víctor Mercante, el decano de la flamante Facultad. Mercante era un célebre educador argentino, identificado con el auge del positivismo autóctono y reconocido por fundar una tradición pedagógica científica, que buscaba apoyarse en los principios de la psicología experimental. A principios de siglo, aunque fuera maestro en una escuela normal de provincia, había publicado dos libros que le dieron cierta notoriedad internacional (MERCANTE, 1904, 1905). Según sus memorias, Théodule Ribot les dedicó un artículo en la Revue Philosophique, al tiempo que, en EEUU, se los premiaba con medalla de oro y diploma de honor en la Exposición Universal de Saint Louis (MERCANTE; 1944 , p. 213) ${ }^{54}$. Pero los reconocimientos recibidos no parecían agotarse allí. En enero de 1905, escribiría por primera vez a Henri Piéron, el célebre psicólogo faerncés: "Leí en la Revue Scientifique un hermoso artículo dedicado a mi libro, y quedo a Ud. deudor de todo mi reconocimiento por los elogios al autor y a la República Argentina" 55 .

Si se tiene en cuenta que Mercante ya comenzaba a codearse con figuras de nivel internacional, no es extraño que en 1906 fuera convocado a formar parte de la UNLP, una casa de altos estudios que pretendía ser una institución pedagógica de avanzada, vinculada con las mejores universidades del mundo occidental. Con este fin, en 1906, en la Facultad de Ciencias Jurídicas, se implementó una Sección Pedagógica para la formación de profesores, cuyo primer director fue Víctor Mercante. Allí comenzó a publicar los Archivos de 
Pedagogía, que, al transformarse la Sección en Facultad (y su director en decano), tomaron el nombre de Archivos de Ciencias de la Educación. Fue entonces en el primer número del órgano de esa nueva institución que apareció el informe de Janet. ¿Pero cuál era el interés de Mercante, que no era médico sino educador, en ese tipo de texto? Podría decirse que era doble, en la medida en que implicaba tanto a Janet como a Freud. Por un lado, Janet era una referencia para toda la psicología científica argentina de la época, particularmente, a partir de su concepción del automatismo psicológico ${ }^{56}$. Por otro lado, Freud, que aún no había sido traducido al castellano, no dejaba de suscitar su interés. Según él, su nombre le era familiar desde 1911, a partir de reseñas publicadas en la Revue Philosophique (MERCANTE, 1927) ${ }^{57}$.

Considerando que las primeras traducciones de Freud al castellano recién iban a producirse en 1922, los cuestionamientos al psicoanálisis fueron conocidos en la Argentina antes que los textos freudianos (VEZZETTI, 1989). En ese sentido, al igual que en Francia, la crítica janetiana, realizada desde un lugar de máxima autoridad, iba a funcionar en la Argentina como matriz de recepción del psicoanálisis, tanto en sus prescripciones como en sus omisiones. Y eso iba a hacerse evidente en figuras como José Ingenieros, un reconocido psiquiatra ítalo-argentino, que, a su vez, tendría una influencia considerable en Mercante así como en la psiquiatría de principios de siglo. En 1904, Ingenieros había publicado un libro cuyo mero título ponía de manifiesto su inspiración charcotiana y janetiana: Los accidentes histéricos y las sugestiones terapéuticas (INGENIEROS; 1904) ${ }^{58}$.

Este autor, que había conocido a Janet (al igual que a Piéron) en el Congreso Internacional de Roma, en 1905, así lo describía en 1906, en una crónica escrita desde París, en la que se refería a la disputa por la sucesión de Ribot en el Collège de France:

Janet tiene mayor preparación clínica, su cultura médica es grande, ha descollado en el estudio de las enfermedades nerviosas y mentales, posee excelentes condiciones de expositor y cuenta varios libros en su haber intelectual. Binet [Alfred] es más hombre de laboratorio, su erudición es vasta, prefiere las investigaciones de psicología pedagógica, es de una dedicación ejemplar y ha escrito libros muy estimados. Janet es más clínico y mejor conferenciante; Binet es un experimentador más diestro [...]. Janet fue nombrado sucesor de Ribot, obteniendo un voto más que Binet, el cual ha quedado como director del laboratorio de psicología experimental. Cada uno en su sitio. Nuestro amigo Th. Ribot, que nos ha referido estos entretelones mientras corregíamos pruebas en la librería de Alcan, no tomó partido por ninguno de ellos. Ambos le parecían dignos de sucederle [...]. Janet es un hombre entre los cuarenta y cinco y cincuenta años, de 
buena presencia, humor risueño, conversación agradable y exquisita amabilidad. Sus estudios clínicos sobre la histeria son de primerísimo orden (INGENIEROS, 1906).

Esta crónica, que dice tanto del lugar de Janet en el campo internacional como del de Ingenieros, ayuda a entender que este último, en su 5으 edición de Histeria y sugestión, de 1919, haya decidido agregar algunos párrafos para criticar el psicoanálisis. Si bien no citaba explícitamente al profesor francés como su fuente, los argumentos eran muy similares a los de su informe de 1913. Era evidente que Ingenieros no había leído a Freud, pero sí a Janet: “Mientras Janet ha procurado profundizar el análisis psicofisiológico de los fenómenos histéricos, deteniéndose en lo inconsciente y en el automatismo psicológico, Freud y Breuer se han especializado en el análisis de sus causas, dentro de un cuerpo de doctrina aplicable a todas las psiconeurosis y conocido con el nombre de 'psicoanálisis'. Desde el punto de vista metodológico no difiere del análisis psicológico, minuciosamente practicado por todos los buenos alienistas [...]. Es indispensable agregar que Freud y sus secuaces parecen deleitarse singularmente en la exposición de sus ideas, dándoles proyecciones ajenas a la medicina y resbalando a un terreno demasiado práctico y mundano" (INGENIEROS, 1919, apud VEZZETTI, 1989, p. 97-98).

Incluso después del ocaso del positivismo en la Argentina, y luego de la muerte de Ingenieros, en 1932, Janet fue recibido con honores en la Facultad de Medicina de la Universidad de Buenos Aires ${ }^{59}$. Un año después, sería invitado a dar una serie de conferencias en Río de Janeiro, donde ya había estado en 1922, con su amigo Georges Dumas, en ocasión del centenario de la independencia del Brasil (SUPPO, 1999).

El cuarto lugar en el que se publicó la crítica de Janet (esta vez traducida al inglés) fue en Boston, en el Journal of Abnormal Psychology, que a su vez era uno de los órganos de la "American Psychological Association" (APA), fundada por Stanley Hall en 1892. La revista comenzó a aparecer en abril de 1906, bajo la dirección de Morton Peabody Prince, un neurólogo graduado de Harvard que, después de una estadía en Francia, en los años '80, entre Nancy y la Salpêtrière, se había convertido en el gran experto norteamericano en trastornos disociativos (que él popularizó bajo la apelación de "personalidades múltiples"). Podría decirse que su lugar en EEUU era en cierto modo comparable al de Janet en Francia, en la medida en que se presentaba como un heredero no ortodoxo de Charcot, mientras que William James elaboraba su propio sistema teórico. Así, según Ellenberger, cuando la tradición charcotiana comenzaba a ser eclipsada en Francia, "fue continuada en Estados Unidos de una forma novedosa, por la llamada Escuela de Psicopatología de Boston, 
en la que Janet encontró sus más grandes seguidores" (ELLENBERGER, 1978).

En ese marco, no es de extrañar que el artículo con el que Morton Prince eligió encabezar el primer número del Journal fuera una contribución del médico y filósofo francés sobre la patogénesis de algunas compulsiones. Si bien David Watson, su director actual, señala que "los artículos de ese número inaugural reflejan el hecho de que sus contenidos tempranos estaban fuertemente influenciados por el psicoanálisis freudiano" (WATSON, 2006, p. 1), podría decirse exactamente lo contrario. En realidad, sólo un trabajo de James Putnam se basaba en las ideas del profesor vienés. Incluso, en todo el segundo volumen, de 1907-1908, no aparecía ni una sola mención a la palabra psycho-analysis, por más que se incluyera un trabajo de Jones (que aún no era psicoanalista). Sin embargo, había dos artículos enteramente dedicados a un simposio sobre el subconsciente, con la participación de Ribot, Janet y Prince, entre otros autores.

Siete años después, si se observa el índice del volumen en el que se publicó el informe de Janet (en dos partes, entre abril y septiembre; JANET, 1914d; 1914e), la situación iba a ser muy diferente. El psicoanálisis iba a atravesar, de un modo u otro, casi todos los artículos. ¿Qué había pasado con "Pierre Janet and his American friends", según rezaba el título del trabajo de Ellenberger? El staff de la revista era prácticamente el mismo: Morton Prince, un admirador de Janet opuesto a las ideas de Freud seguía siendo el director. Al igual que en 1906, lo acompañaban James Putnam y Hugo Münsterberg (ambos profesores de Harvard), Boris Sidis (un médico ruso discípulo de William James, igualmente crítico del psicoanálisis), y Adolf Meyer (un psiquiatra suizo que enseñaba en la Johns Hopkins University), entre otros ${ }^{60}$. A ese nivel, la diferencia mayor había sido la incorporación de Ernest Jones, que de articulista ocasional había pasado a ser director asistente, al mismo tiempo que, en ese período, se había transformado en un psicoanalista cercano a Freud. Asimismo, durante su estancia en Toronto, había tenido un rol fundamental en la institucionalización del psicoanálisis en América del Norte. Ya en 1908 había visitado a Prince en Boston, y en 1909 convenció a Putnam de organizar un simposio norteamericano de psicoterapia en New Haven (GROSSKURTH, 1990, p. 172). Ese mismo año participó activamente en la organización de las conferencias de Freud en la Clark University (en Worcester, Massachusetts), que tuvieron un éxito considerable. $Y$, finalmente, en 1911, fue cofundador de la American Psychoanalytic Association, de la que Putnam sería el primer presidente. Es decir que, en esos años, Jones había realizado un intenso trabajo de lobbying con "los amigos norteamericanos" de Janet, mientras el psicoanálisis era adoptado por figuras prominentes de la psiquiatría y la neurología (como el mismo 
Putnam y Abraham Brill).

En todo caso, el informe de Janet fue publicado íntegramente, con lo cual esta versión, traducida al inglés, venía a sumarse a las ediciones castellana, alemana y francesa, que habían aparecido a lo largo de ese año. En el mismo volumen de la revista, en el último número, Ernest Jones ejercía su derecho de réplica, pero ya no como mero espectador - que exageraba duelos imaginarios, como en 1913-, sino como director asistente que, además, ya había fundado dos asociaciones analíticas. Desde esa posición, Jones se permitiría decir entonces lo que antes sólo había fabulado en su correspondencia con Freud: “La crítica del psicoanálisis que el profesor Janet leyó el año pasado en el Congreso Internacional de Londres contenía varios pasajes cuya naturaleza y cuya tendencia los hacían susceptibles de una seria acusación de injusticia deliberada [...]. En lo que a mi respecta, no obstante, las cosas habrían quedado allí, si no fuera porque el profesor Janet eligió volver a publicar su trabajo, que ya figuraba en las Actas Oficiales del Congreso, tanto en el Journal de Psychologie como en el Journal of Abnormal Psychology, sin rectificar ni uno solo de los errores cometidos en la versión original" (JONES, 1915, p. 401) ${ }^{61}$. Así, a lo largo de diez páginas, el médico galés se dedicaba a señalar cada uno de esos errores, ensayando una incisiva crítica de la crítica. Los golpes que no había podido asestar en persona, en un duelo que nunca se había producido, se terminaban traduciendo en contra-argumentos, que nunca serían respondidos.

No obstante lo anterior, todavía en 1914, Sigmund Freud reafirmaba su fe en el relato del discípulo que, gracias a su fidelidad, había sabido ganarse la confianza de su maestro. De modo que, en su "Historia del movimiento analítico", volvería una vez más a comentar los sucesos de 1913 según la versión inventada por el médico galés:

\footnotetext{
En París parece reinar aún la convicción, tan elocuentemente expresada por Janet en el Congreso Médico Internacional de Londres, de que todo lo bueno del psicoanálisis no hace sino repetir, con escasas modificaciones, las opiniones del propio Janet, siendo absolutamente rechazable lo demás. En este mismo Congreso tuvo Janet que tolerar una serie de rectificaciones por parte de E. Jones, el cual le demostró su escaso conocimiento de la materia. No obstante, nos es imposible olvidar, aun rechazando las aspiraciones en tal ocasión manifestadas, los grandes merecimientos de Janet en la psicología de las neurosis (FREUD, 1914, p. 901).
}

Los años subsiguientes implicaron aún una serie de críticas cruzadas entre Freud y Janet que, si bien guardaban la misma forma amable, no dejaban de recordar los puntos en conflicto. Sin embargo, en los años '20 y '30 las referencias mutuas prácticamente desaparecieron. El último capítulo de esta historia es conocido, y forma parte de la leyenda del movimiento analítico. En 1937, cuando Freud ya tenía 80 
años y Janet 78, este último quiso visitarlo en Viena, por lo que su yerno Edouard Pichon (uno de los fundadores de la Société Psychanalytique de Paris, que había sido impulsor de una suerte de freudo-janetismo) trató de interceder por escrito. Freud no respondió su carta, pero hizo saber su opinión a Marie Bonaparte:

\begin{abstract}
No, no veré a Janet. No podría dejar de reprocharle su conducta desleal para con el psicoanálisis y también con mi persona, sin desdecirse en ningún momento [...]. No, no lo veré. Pensé al comienzo en ahorrarle esa descortesía mediante la excusa de que no me siento bien o de que ya no puedo hablar en francés, y él, con seguridad, no sabe una palabra de alemán. Pero he decidido no proceder así. No hay razón para que yo haga sacrificio alguno por él. Sinceridad es la única actitud posible: la grosería se justifica (JONES, 1957, p. 546).
\end{abstract}

Roudinesco y Plon agregan una página más a este relato. Pese a todo, en el mes de abril, Janet llamó a la puerta del número 19 de la calle Bergasse. Y el ama de llaves le respondió que el profesor no se encontraba (ROUDINESCO; PLON, 1997) ${ }^{62}$. ¿Este desencuentro final entre un Freud orgulloso y un Janet humillado sería una metáfora del triunfo definitivo del psicoanálisis por sobre la psicología de Janet? Quizás, en parte. No puede desconocerse que, para esa época, Freud era una figura muy reconocida en la cultura a nivel internacional, a la vez que sus doctrinas parecían imponerse en los más diversos ámbitos. Pero tampoco puede ignorarse que Janet seguía gozando de una gran reputación en los círculos académicos especializados, de tal suerte que, el año anterior, había sido invitado a Boston para dar una serie de conferencias y para celebrar el bicentenario de la Universidad de Harvard. En 1937, en Viena, cuando Freud negó su presencia, sí fue recibido por el premio Nobel Julius Wagner-Jauregg. Finalmente, en París, en 1938, Henri Wallon lo invitó a publicar una síntesis de su sistema psicológico, que terminó denominando "psicología de la conducta", en la prestigiosa Encyclopédie Française (JANET, 1938). En 1939, Jean Piaget le rendiría un cálido homenaje, mientras que en 1947, el año de su muerte, Daniel Lagache retomaría su proyecto, una vez más, tratando de conciliarlo con el psicoanálisis (LAGACHE, 1947).

\title{
10 Conclusiones
}

A lo largo de este trabajo hemos abordado las relaciones entre Pierre Janet y Sigmund Freud, enfocándonos en dos momentos puntuales. En primer lugar (luego de un breve pasaje por la tesis doctoral de Janet, de 1889), nos hemos detenido en el período 1893-1895, en el 
que se produjeron las primeras referencias mutuas entre ambos autores en torno de las neurosis en general y de la histeria en particular. Para ese entonces, el profesor francés, que se presentaba como un científico ateórico, sólo guiado por los hechos, en realidad, ya había ideado un complejo sistema psicológico, basado en principios que habían logrado un consenso bastante generalizado en la comunidad de especialistas de la época (como el automatismo psicológico, la debilidad de síntesis y la disociación de la conciencia). En el plano de la práctica psicoterapéutica, no obstante, recurría a una pluralidad de métodos y procedimientos.

En ese marco, Janet, que ya gozaba de cierta reputación, tomaba los primeros trabajos de Freud como los de un recién llegado que, de un modo u otro, venía a confirmar sus propios descubrimientos. En todo caso, hemos mostrado que no puede hablarse allí de una querella por la paternidad del psicoanálisis (que aún no había nacido como tal), sino de posiciones teóricas, metodológicas y epistemológicas divergentes sobre la causa y el tratamiento de las neurosis. Si bien ambos autores habían partido de puntos muy similares (los dos utilizaban la hipnosis y se presentaban como discípulos de Charcot), rápidamente se fueron diferenciando, a tal punto que ya en esa época se perfilaban la mayor parte de las divergencias que iban a separarlos por más de cuatro décadas (en torno de la forma de concebir lo no conciente, del carácter primario o secundario de la disociación de la conciencia, de la naturaleza de los recuerdos traumáticos, etc.).

Por otra parte, respecto de este breve período, hemos subrayado la importancia desmesurada que la historiografía (incluso los historiadores más rigurosos) ha dado a la expresión "análisis psicológico" para oponerla al método catártico, primero y al psicoanálisis, después. En los textos de esa época, si bien Janet utilizaba ocasionalmente esos términos, lo hacía en un sentido inespecífico, para referirse a un método de estudio de los fenómenos psíquicos, y no a un procedimiento terapéutico unificado. Algo similar hemos constatado con el concepto de "subconsciente", que Janet utilizaba en esos años como adjetivo calificativo (aplicable a actos, hechos, pensamientos, ideas, estados, etc.), pero no como sustantivo que, en un sentido tópico, pudiera oponerse al inconsciente freudiano. Recién en 1913, en su crítica del freudismo, Janet se vería en la necesidad retórica de proponer términos alternativos, tanto para el psicoanálisis como para el inconsciente postulado por Freud. Pero incluso en ese momento ( $y$ es lo que hemos tratado de demostrar), "el análisis psicológico" y "el psicoanálisis", "el subconsciente" y "el inconsciente" no podían oponerse de manera simétrica. Menos aún debería proyectarse esa supuesta simetría, de manera retrospectiva, a un pasado en el que esos términos no eran utilizados o tenían un valor muy distinto.

En un segundo momento, que va de 1913 a 1915, nos hemos 
detenido específicamente en la crítica de Janet: en su contexto, en sus contenidos, en el debate que suscitó y en el impacto que tuvo en países muy diversos. Respecto de su contexto, hemos mostrado hasta qué punto se trataba de un congreso internacional de máxima relevancia, al que asistían las figuras más destacadas de las distintas subdisciplinas médicas, lo cual contribuye a entender la difusión que ese informe iba a terminar logrando. En cuanto a su contenido, hemos constatado que no agregaba gran cosa respecto de los intercambios producidos entre 1893 y 1895, época a la que seguía refiriéndose, como si el paso del tiempo no hubiera modificado las ideas de Freud. Respecto de los temas más actuales, en ausencia de traducciones al francés, Janet se basaba en diversas reseñas y críticas, sobre todo norteamericanas. Lo asombroso es que en lo tocante a la sexualidad infantil y a los determinismos inconscientes dejaba de lado la argumentación de los textos que él mismo citaba. Al mismo tiempo, ponía en boca de Freud afirmaciones que en realidad provenían de sus críticos. En suma, aún con sus errores y lagunas, sin aspirar a mayor originalidad, el informe resumía las críticas más comunes que se habían formulado hasta entonces en contra del psicoanálisis.

En el plano epistemológico, podría sostenerse que la crítica más fuerte del profesor francés señalaba que el psicoanálisis tomaba la parte por el todo. Por ejemplo, en el caso de los recuerdos traumáticos o de la sexualidad, se apropiaba de hipótesis parciales, que no eran de por sí originales. Pero luego las convertía en postulados (es decir, en verdades que debían aceptarse como tales sin necesidad de contrastación empírica), y trataba de aplicarlas a todos los casos, como si se tratara de principios matemáticos a priori. Peor aun, para Janet, esas hipótesis eran a menudo aventuradas y se basaban en errores, exageraciones y generalizaciones injustificadas. Es decir que, en vez de atenerse a los hechos, forzaban su interpretación, utilizando un lenguaje vago y metafórico. Todo lo anterior lo hacía ubicar al psicoanálisis en un terreno filosófico, e incluso religioso, mientras que su propio análisis psicológico, supuestamente basado en la observación y en la inducción, se presentaba como una verdadera disciplina científica, capaz de prestar servicios a la psiquiatría y a la neurología, de las que había surgido.

La discusión posterior al informe de Janet (por no decir todo el congreso) ha sido presentada muchas veces como un evento crucial, como una batalla decisiva que habría definido la "guerra" entre el psicoanálisis y el análisis psicológico en favor del primero. Si bien la expansión creciente del psicoanálisis en esa época y la declinación progresiva de la psiquiatría dinámica no pueden soslayarse, tampoco pueden ser atribuidas a un único evento histórico. Más aún, en lo tocante al Congreso de Londres, las fuentes tienden a impugnar los relatos históricos sesgados, basados principalmente en la fantasiosa 
correspondencia de Jones y en el crédito que Freud le dio en sus propios escritos. Si se examinan de cerca los dichos de los participantes, se llega a la conclusión de que ese encuentro no sólo no habría implicado una clara victoria del psicoanálisis, sino más bien todo la contrario (sobre todo si se presta atención a la intervención de Jung, que, más allá de sus declaraciones de propósitos, terminó abonando las teorías del francés y criticando las de su futuro exmaestro vienés).

Por otra parte, si la discusión hubiera sido tan favorable al psicoanálisis como afirmaba Jones (quien se jactaba de haber tenido un rol definitorio en el resultado de esa contienda), no se entiende muy bien por qué nunca fue reproducida por ninguna revista analítica. Sin embargo, sí se reprodujo la intervención de Janet, que en menos de un año se publicó en lugares tan dispares como Viena, París, Boston y La Plata, además de aparecer en Londres, en las actas del congreso. ¿Pero cuál sería la razón del "éxito" de esa crítica? ¿Esa difusión tan rápida como extendida implicaría que, en realidad, fue Janet el que salió victorioso del encuentro de Londres? No parece tan claro. En realidad, mirando con atención los múltiples "nichos" en los cuales fue recepcionada esa crítica, el interés que la motivó aparenta haber sido doble. Por un lado, parecía valorarse el comentario de las teorías freudianas, que generaban la curiosidad de los círculos más diversos. Pero al mismo tiempo, no era indiferente que el autor de ese informe crítico fuera Pierre Janet, cuya reputación en la materia no dejaba de ser reconocida. Finalmente, más allá de sus errores y lagunas, esa crítica no sólo parece haber sintetizado los principales argumentos de críticas anteriores, sino que no sería aventurado afirmar que también serviría de matriz a las críticas que iban a realizarse al psicoanálisis a lo largo de todo un siglo, incluyendo las más actuales.

En cuanto a las coordenadas que sitúan la oposición entre Janet y Freud, Ellenberger ubica al primero como un representante de la Ilustración, mientras que el segundo habría sido un heredero del romanticismo alemán. Para Hacking, en cambio, el médico francés era "un hombre honorable de la Tercera República". "Janet era flexible y pragmático, mientras que Freud era un teórico dedicado y bastante rígido", dispuesto a alcanzar la verdad sin importarle los medios. "Janet no tenía ningún reparo en mentirles a sus pacientes, creándoles falsos recuerdos con los que pudiesen soportar su aflicción. La verdad no era para él un valor absoluto" (HACKING, 1995, p. 9-10) ${ }^{63}$. Para otros autores, Janet simplemente había sido un terapeuta ecléctico, que se inspiraba en las viejas curas magnéticas. "Finalmente se tiene la impresión de que su principal preocupación terapéutica no es la evocación de los recuerdos sino el aprendizaje del olvido" (CARROY; OHAYON; PLAS, 2006, p. 84). 


\section{Referencias}

ACHER, R. Recent freudian literature. The American Journal of Psychology, v. 22, p. 428-443, 1911.

BREUER, J.; FREUD, S. El mecanismo psíquico de los fenómenos histéricos (comunicación preliminar). En: FREUD, S. Obras completas (tomo I ). Madrid: Biblioteca Nueva, 1893, p. 25-32.

CARROY, J. ; PLAS, R. Janet, Pierre. Complete dictionary of scientific biography. Nueva York: Charles Scribner's Sons, 2008.

CARROY, J.; OHAYON, A.; PLAS, R. Historia de la psicología en Francia. París: La Découverte, 2006.

CORIAT, I. H. Some personal reminiscences of psychoanalysis in Boston: an autobiographical note. The Psychoanalytic Review, v. 32, p. 1-8, 1945.

CHARCOT, J-M. Préface. En: JANET, P. L'État mental des hystériques: les stigmates mentaux. París: Rueff, 1893.

CHARMA, A. Du sommeil. Observation scientifique. Caen: Mémoire de l'Académie des sciences, 1851.

DAGFAL, A. La psychanalyse à l'intérieur de la psychologie: les avatars du projet de Daniel Lagache. Essaim, v. 9, p. 33-51, 2002.

Psychanalyse et psychologie: París-Londres-Buenos Aires. París: Campagne Première, 2011.

DISCUSSION. Psycho-analysis. Report to the Section of Psychiatry, XVI I ${ }^{\text {th }}$ I nternational Congress of Medicine, London, 1913. Londres: Henry Frowde. Sección XII, Psiquiatría, Parte 1, p. 65-71, 1913.

ELLENBERGER, H. El descubrimiento del inconsciente. Historia y evolución de la psiquiatría dinámica. Madrid: Gredos, 1976.

Pierre Janet and his American friends. En: GIFFORD, G.E. (Comp.). Psychoanalysis, psychotherapy and the New England medical scene. 1894-1944. Nueva York: Science History Publications, 1978, p. 63-72.

FREUD, S. Estudio comparativo de las parálisis motrices orgánicas e histéricas. En: FREUD, S. Obras completas (tomo I). Madrid: Biblioteca Nueva, 1893a, p. 193-199.

. Charcot. En: FREUD, S. Obras completas (tomo I). Madrid: Biblioteca Nueva, 1893b, p. 17-23.

. Las neuropsicosis de defensa. En: FREUD, S. Obras completas (tomo I). Madrid: Biblioteca Nueva, 1894, p. 175-180.

. Estudios sobre la histeria. Historiales clínicos. La señora Emmy de N. En: Obras completas (tomo I). Madrid: Biblioteca Nueva, 1895, p. 33-63.

Über "wilde" Psychoanalyse. Zentralblatt fur Psychoanalyse, 1, p. 91-95. Versión castellana (1948). El psicoanálisis "silvestre". En : Obras completas (tomo II). Madrid: 
Biblioteca Nueva, 1910, p. 315-318.

. (1914). Historia del movimiento psicoanalítico. En: FREUD, S. Obras completas (tomo II). Madrid: Biblioteca Nueva, 1948, p. 889-919.

(1913). Carta a Jones (10 de agosto). En : PASKAUSKAS, A. (Comp.). The complete correspondence of Sigmund Freud and Ernest Jones (1908-1939). Cambridge /Londres: Belknap Press, 1993, p. 217-218.

GAY, P. Freud: a life for our time. London: Papermac, 1988.

GRAF, M. Richard Wagner im "Fliegenden Holländer." Ein Beitrag zur Psychologie des künstlerischen Schaffens. LeipzigVienna: F. Deuticke, 1911.

GROSSKURTH, P. Melanie Klein. Su mundo y su obra. Buenos Aires: Paidós, 1990.

HACKING, I. Rewriting the soul. Multiple personality and the sciences of memory. Princeton: Princeton University Press (trad. cast. capítulos 13 y 14 de A. Kripper, 1995. Disponível em: <http://www.elseminario.com.ar>.

HALE, N. From Berggasse XIX to Central Park West: The Americanization of psychoanalysis, 1919-1940. Journal of the History of the Behavioral Sciences, v. 14, p. 299-315, 1978.

HESNARD, A. Réflexions sur la Psychologie de Pierre Janet (A propos d'un livre récent). Revue française de Psychanalyse, v. 4, n. 1, p. 625-646, 1927.

INGENIEROS, J. Los accidentes histéricos y las sugestiones terapéuticas. Buenos Aires: J. Menéndez, 1904.

INGENIEROS, J. Psicólogos franceses. Diario La Nación, 13 de octubre 1906 , p. 5.

Histeria y sugestión. Psicología clínica. 5.ed. Buenos Aires: L.J . Rosso \& Cia, 1919.

JANET,P. L'automatisme psychologique. Essai de psychologie expérimentale sur les formes inférieures de l'activité humaine. París: Alcan, 1889.

- L'anesthésie hystérique. Conférence faite à la Salpêtrière le $\overline{1} 1$ mars 1892. Archives de Neurologie, v.23, p.323-352, 1892a.

L'amnésie hystérique. Deuxième conférence faite à la Salpêtrière le 17 mars 1892. Archives de Neurologie, v. 24, p.29$55,1892 b$.

- La suggestion chez les hystériques. Troisième conférence faite à la Salpêtrière, le ler avril 1892. Archives de Neurologie, v. 24, p. 448-470, 1892c.

. Contribution à l'étude des accidents mentaux chez les hystériques. 1893a. Tesis (Doctoral en Medicina) - Faculté de Médecine de la Sorbonne, París, 1893a.

L'État mental des hystériques: Les stigmates mentaux. 1. ed. París: Rueff, 1893b. 
. Quelques définitions récentes de I'hystérie (I). Archives de Neurologie, v. 76, n. 25, p. 417-438, 1893c.

Quelques définitions récentes de I'hystérie (II). Archives de

Neurologie, v. 77, n. 26, p.1-29, 1893d.

Histoire d'une idée fixe. Revue Philosophique de la

France et de l'Etranger, v. 37, p.121-168, 1894a.

Névroses et idées fixes (I ). París: Alcan, 1898.

The pathogenesis of some impulsions. Journal of

Abnormal Psychology, v. 1, n. 1, p. 1-17, 1906.

$\overline{1} \overline{9} \overline{7}$.

The major symptoms of hysteria. Londres: Macmillan,

L'analyse psychologique et la critique des méthodes de psychothérapie. Annuaire du Collège de France, v. 8, p. 7071,1908a.

. L'hystérie maladie mentale. En: VAN WAYENBURG, G. A. M. (Ed.). Compte rendu des travaux du premier congrès international de psychiatrie, de neurologie, de psychologie et de l'assistance aux aliénés, tenu à Amsterdam du 2 au 7 septembre 1907 .Amsterdam: J. H. de Bussy. 1908b, p. 264-270.

L'analyse des tendances et les lois de leur réalisation. Annuaire du Collège de France, v. 10, p. 37-38, 1910. (1894a). L'État mental des hystériques. Les accidents mentaux. 2.ed. París: Rueff, 1911a.

L'analyse de la perception du monde extérieur. Annuaire du Collège de France, v.11, p. 88-91, 1911b.

Psycho-analysis. Report to the section of Psychiatry, $\overline{\mathbf{X}} \mathbf{V} \mathbf{I}^{\mathbf{t h}^{-}}$International Congress of Medicine. Londres: Henry Frowde. Sección XII, Psiquiatría, Parte 1, 1913, p. 13-64.

Janet über die Psychoanalyse. Zentralblatt für Psychoanalyse und Psychothérapie, v. 4, p. 309-316, 1914b.

. El psico-análisis. Archivos de Ciencias de la Educación, v. $\overline{1}, \bar{p} . \overline{1} \overline{7} 5-229,1914 \mathrm{c}$.

. Psychoanalysis. Journal of Abnormal Psychology, v. 9, n. 1, p. 1-35, 1914d.

. Psychoanalysis. Journal of Abnormal Psychology, v. 9, n. 2/3, p. 153-187, 1914e.

Valeur de la psycho-analyse de Freud. Revue de Psychothérapie et de Psychologie Appliquée, v. 29, n. 3/4, p. 8283, 1915.

Psychologie de la conduite. En: Encyclopédie Française, tomo VIII, "La vie mentale" fasc. 8. París: Société de Gestion de l'Encyclopédie Française, 1938, p. 11-16.

(1930). Pierre Janet. En: MURCHISON, C. (Comp.). A history of psychology in autobiography. v. 1. Worcester: Clark University Press: 1961, p. 123-133.

(1914a). La psycho-analyse. Journal de Psychologie 
Normale et Pathologique, v.11, p. 1-36; 97-130, París: L'Harmattan, 2004.

JANET, P.; LEGUEU, F. La vie scientifique en Argentine. En: DAIREAUX, $M$. et al. Initiation à la vie en Argentine. París: Armand Colin, 1935, p. 156-174.

JONES, E. The pathology of morbid anxiety. Journal of Abnormal Psychology, v. 6, n.2, p. 81-106, 1911.

$1913 a$.

Papers on psychoanalysis. Nueva York: Wood \& Co.,

Professor Janet on psycho-analysis; a rejoinder. Journal of Abnormal Psychology, v.9, n.4, 1915, p. 400-410.

Professor Janet über Psychoanalyse. Internationale

Zeitschrift für Psychoanalyse, v.4, 1916, p. 34-43.

(1954). The life and work of Sigmund Freud (tomo II).

The years of maturity (1901-1919). Nueva York: Basic Books, 1985a.

. (1957). The life and work of Sigmund Freud (tomo III). The last phase (1919-1939). Nueva York: Basic Books. Barcelona: Salvat, 1985b.

(1913b). Carta a Freud (8 de agosto). En: PASKAUSKAS, A. (Comp.). The complete correspondence of Sigmund Freud and Ernest J ones (1908-1939). Cambridge /Londres: Belknap Press, 1993, p. 215-216.

JUNG, C. G. Wandlungen und Symbole der Libido: Beiträge zur Entwicklungsgeschichte des Denkens. Leipzig y Viena: Franz Deuticke, 1912.

Über Psychoanalyse. (extractos). Zentralblatt für Psychoanalyse und Psychothérapie, v. 4, p. 316, 1914.

Símbolos de transformación. Buenos Aires: Paidós, 1982.

LA'DAME, P.-L. Névrose et sexualité (I). L'Encéphale. Journal de Neurologie et de Psychiatrie, v.8, n.1, p. 53-72, 1913 a.

Névrose et sexualité (II). L'Encéphale. Journal de Neurologie et de Psychiatrie, v. 8, n. 2, p. 160-179, $1913 \mathrm{~b}$. LAGACHE, D. (1947). La unidad de la psicología. Buenos Aires: Paidós, 1969.

LAGACHE, D. (1949). Psicología clínica y método clínico. En:

Obras III : De la homosexualidad a los celos. Psicología y método clínicos. Otros estudios. Buenos Aires: Paidós, 1982, p. 141-156.

LANGE, F. (1875). Histoire du matérialisme et critique de son importance à notre époque. París: C. Reinwald et Cie, 1879.

LEYS, R. Traumatic cures: shell shock, Janet and the question of memory. En: LEYS, R. Trauma: a genealogy. Chicago: University of Chicago Press, 2000, p. 83-117.

LEFRERE J.-J.; BERCHE, P. Un cas de délire scientifico-patriotique: le docteur Edgar Bérillon. Annales médico-psychologiques, v. 168, n. 9, p.707-711, 2010. 
MAEDER, A. Sur le mouvement psychoanalytique : un point de vue nouveau en psychologie. L'Année psychologique, v.18, p. 389-418, 1912.

MEINONG, A. Beiträge zur Theorie der psychischen Analyse. Zeitschrift für Psychologie und Physiologie der Sinnesorgane, v. 6, p. 340-385, 1894.

MERCANTE, V. La paidología: estudio del alumno. Buenos Aires: M. Glazer, 1927.

Una vida realizada: mis memorias. Buenos Aires: Imprenta Ferrari Hnos, 1944.

MONAHAN, P. C.G. Jung: Freud's heir or Janet's? The influence upon Jung of Janet's dissociationism. International Journal of J ungian Studies, v. 1, n. 1, p. 33-49, 2009.

NICOLAS, S. Préface de l'éditeur. En: JANET, P. La psychanalyse de Freud. París: L'Harmattan, 2004, p. 5-48.

PRÉVOST, C. Janet, Freud et la psychologie clinique. París: Petite Bibliothèque Payot, 1973a.

La psycho-philosophie de Pierre Janet: économies mentales et progrès humain. París: Payot, 1973b.

PUTNAM, J.J. Personal impressions of Sigmund Freud and his work, with special reference to his recent lectures at Clark University. The Journal of Abnormal Psychology, v. 4, n. 6, p. 372-379, 1910.

RÉGIS, E. ; HESNARD, A. La doctrine de Freud et de son école (I). L'Encéphale, v. 8, p. 356-378, $1913 a$.

. La doctrine de Freud et de son école (II). L'Encéphale, v. 8, p. $446-481,1913 b$.

. La doctrine de Freud et de son école (III). L'Encéphale, v. 8, p. 537-564, 1913c.

ROMERO, E. Pierre Janet en Buenos Aires. Etcétera, v. 85, n. 1, 2007.

ROUDINESCO, É. Histoire de la psychanalyse en France (tomo I, 1885-1939). París: Fayard, 1994.

ROUDINESCO, É. ; PLON, M. Dictionnaire de la psychanalyse. París: Fayard, 1997.

ROAZEN, P. Freud and his followers. New York: Knopf, 1975.

STRACHEY, J. Editor's introduction. En: BREUER, J.; FREUD, S. Studies on hysteria: 1893-1895. New York: Basic Books, 1957, p. ix-xxviii.

SULLOWAY, F. Freud, biologist of the mind: beyond the psychoanalytic legend. London: Basic Books, 1979.

SUPPO, H.R. La politique culturelle française au Brésil entre les années 1920-1950. 1999. Tesis (Doctorado en Historia) Université Paris III - Sorbonne Nouvelle, Paris, 1999.

TALAK, A. La invención de una ciencia primera. Los primeros desarrollos de la psicología en la Argentina (18961919). 2008. Tesis (Doctorado en Psicología) - Facultad de Filosofía 
y Letras, Universidad de Buenos Aires, Buenos Aires, 2008.

VAN DER HART, O. I an Hacking on Pierre Janet: observations. Dissociation, v. 9, n. 1, p. 80-84, 1996.

VALSINER, J .; VAN DER VEER, R. Pierre J anet's world of tensions. En: VALSINER, J.; ; VAN DER VEER, R. The social mind: construction of the idea. Cambridge: Cambridge University Press, 2000, p. 97-101 y p. $122-137$.

VEZZETTI, H. (Comp.). Freud en Buenos Aires: 1910-1939. Buenos Aires: Puntosur, 1989.

VOLKELT, J. Psychologische Streitfragen (III). Zeitschrift für Philosophie und philosophische Kritik, v. 102, p. 44-74, 1893. WATSON, D. Into the second century. Journal of Abnormal Psychology, v. 115, n. 1, p. 1-4, 2006.

\author{
Endereço para correspondência: \\ Alejandro Antonio Dagfal \\ Instituto de Investigaciones, Facultad de Psicologia de la UBA \\ Gral. Juan Lavalle 2353 \\ (C1052AAA) Buenos Aires, Argentina \\ Telefone: +54 2214530924 \\ e-mail: adagfal@club-internet.fr
}

Recebido em: 27/07/2013

Aceito para publicação em: 14/08/2013

Acompanhamento do processo editorial: Ana Maria Jacó Vilela

\title{
NOTAS
}

* Psicólogo (UNLP, Argentina) doutor e mestre em História (Paris VII) e pesquisador adjunto (CONICET). Tem atuado como docente-pesquisador nas universidades de Bretagne Occidentale e Lyon I, como professor convidado na École des Hautes Études en Sciences Sociales e professor titular na UNLP. Atualmente está a cargo da matéria História da Psicologia (cátedra I) na Universidade de Buenos Aires.

1 Si bien el término "conflicto" no es privilegiado por Janet (y suele asociarse exclusivamente a la idea de "conflicto psíquico", promovida por Freud), consideramos que también puede aplicarse, de manera restringida, a algunas de las concepciones del filósofo francés.

2 Aunque en este pasaje Janet habla de "actos inconscientes", más adelante reemplazará ese término por el de "subconsciente", utilizado en sentido descriptivo, como adjetivo calificativo sinónimo de "latente". Así, se referirá a actos, hechos, pensamientos, ideas (fijas o no), fenómenos y estados "subconscientes", pero también a sensaciones, sensibilidades, personajes, personalidades, movimientos, vidas, existencias, sistemas psicológicos, escrituras, signos, palabras, alucinaciones y sugestiones "subconscientes". También lo utilizará como adverbio de modo, por ejemplo, para actos realizados "subconscientemente". En un único párrafo de este libro se detiene Janet a aclarar el significado de este término que él mismo había acuñado. "Esta expresión [la de inconsciente], aplicada a los hechos precedentes, ya no tiene sentido. ¿Qué es un juicio inconsciente, una multiplicación inconsciente? 
Si la palabra es para nosotros un signo de la consciencia ajena, ¿por qué la escritura no sería un signo característico de ella? Estos fenómenos parecen pertenecer a una conciencia particular, por debajo de la conciencia normal del individuo. No es ésta una explicación, sin duda; es la constatación de un hecho, por extraño que parezca. Y no haremos más que resumir estas observaciones, de aquí en adelante, llamando a esos actos hechos subconscientes, que tienen una conciencia por debajo de la conciencia normal. Aunque, cuando los conozcamos mejor, debamos retomar con más precisión la cuestión de su naturaleza" (J ANET, 1889 , p. 265). En resumen, para Janet, todo lo subconsciente (actos, fenómenos, etc.) no era inconsciente, en el sentido de la tradición romántica alemana, sino que, en la línea del racionalismo francés, revestía otra forma de conciencia, más primaria y debilitada que la conciencia normal. La traducción de la cita es nuestra, al igual que la de todos los textos en los que no se haga referencia a una versión castellana.

${ }^{3}$ La frase entrecomillada es una cita textual del segundo tomo de la Histoire du matérialisme de Frederic Lange, publicado en 1875 en Alemania y traducido al francés en 1879 (LANGE, 1875, p. 427, 20 tomo, apud JANET, 1889, p. 4). Janet sitúa erróneamente el 2 tomo en 1877, fecha de publicación del 1 tomo.

${ }^{4}$ A la luz de precisiones etiológicas posteriores, la redacción más correcta para este párrafo habría sido "por la predisposición al sonambulismo que las engendra". De lo contrario, Janet parecería afirmar que era la histeria la que engendraba la predisposición y no a la inversa.

${ }^{5}$ A su vez, además de dividir el automatismo en total y parcial (según la extensión de la personalidad comprometida), Janet postulaba "existencias simultáneas" y "sucesivas", teorización que luego dio lugar a los conocidos debates sobre las "personalidades múltiples". Cabe destacar que, en ese momento, prefería hablar de "desagregación" o de "desdoblamiento" (de la conciencia, del yo o de la personalidad) y no de "disociación", término que había empleado en escritos anteriores y que continuaría utilizando en el futuro, pero que no aparece mencionado en este trabajo.

${ }^{6}$ No vamos a detenernos aquí en cuestiones biográficas. Por esa razón, remitimos al lector a la inmensa bibliografía existente sobre ambos autores. Sobre Freud, particularmente, aconsejamos la lectura de Gay (1988), Sulloway (1979), Roazen (1975). Sobre Janet, véanse Prévost (1973a, 1973b), Ellenberger (1976) y Nicolas (2004).

${ }^{7}$ Es sabido que Freud realizó una breve estancia en el servicio dirigido por Charcot, en la Salpêtrière, entre 1885 y 1886, mientras que Janet pasó allí más de veinte años, entre 1890 y 1910 , en el mismo servicio, para continuar luego, durante algunos años más, en el servicio dirigido por su amigo Jean Nageotte.

8 Freud se refería sin duda a tres conferencias pronunciadas por Janet en la Salpêtrière ("L'Anesthésie hystérique", "L'Amnésie hystérique" y "La Suggestion chez les hystériques") entre marzo y abril de 1892 y que habían sido publicadas ese mismo año (J ANET 1892a, 1892b, 1892c).

9 La itálica parece ser de Breuer y Freud, según la tipografía de las ediciones castellanas.

${ }^{10}$ Freud venía refiriéndose a la teoría según la cual "la disociación de la conciencia es un rasgo primario de la modificación histérica y depende de una debilidad congénita de la capacidad de síntesis psíquica". Citaba explícitamente la tesis doctoral de medicina que Janet había defendido el año anterior, que acababa de publicarse (JANET, 1893a, 1894). Citaba además otro artículo, publicado en junio de 1893, en el que Janet había respondido los comentarios que Breuer y Freud habían publicado en enero, según veremos a continuación (J ANET, 1893c).

${ }^{11}$ Se trata del mismo artículo que Freud, a su vez, citaría en 1894.

${ }^{12}$ Esa fue, por ejemplo, la opinión de Strachey, quien destacó la acogida laudatoria de Janet, diciendo que su "resistencia a las ideas freudianas iba a desarrollarse más 
tarde (STRACHEY, 1957).

${ }^{13}$ Las dos partes de este trabajo (Les Stigmates mentaux y Les Accidents mentaux) recién iban a reunirse en la segunda edición de L'État mental des hystériques, en cuyo prólogo (que precedía al prefacio de Charcot) el médico francés aclaraba este embrollo editorial (JANET, 1910). De todos modos, esa primera parte publicada en 1893 suele confundirse en la bibliografía con la tesis misma, que constituía en realidad una segunda parte. Serge Nicolas es una excepción a esta regla. Incluso aporta una copia de la portada de ese libro en su sitio "Pierre Janet (1859-1947)". Disponible

<https://sites.google.com/site/pierrejanet18591947/home/oeuvres>.

${ }^{14}$ La cursiva es nuestra.

${ }^{15}$ La traducción es de Janet, que cita a "Breuer y Freud. Op. cit., 4", aunque la referencia completa recién aparezca en la página 269: “Joseph Breuer y Sigm. Freud, de Viena". Ueber den psychischen Mechanismus hysterischer Phänomene (vorläufige Mittheilung). Neurologisches Centralblatt, 1893, v. 12, n. 1, p. 4-10 y n. 2, p. 43-47.

${ }^{16}$ Del mismo modo, en esa misma época, ya utilizaban esa expresión otros autores, incluso germanoparlantes, como Alexius von Meinong (1894) y Johannes Volkelt (1893), quienes hablaban de "psychischen Analyse".

${ }^{17}$ Respecto de este tema, véase la discusión entre Ian Hacking y Onno van der Hart (HACKING, 1995; VAN DER HART, 1996).

18 Para un resumen de esos primeros casos, en Le Havre y la Salpêtrière, véase Ellenberger (1976), Valsiner; Van der Veer (2000).

${ }^{19}$ Ya en esa época, sin hacer referencia al psicoanálisis, criticaba la generalización indebida del hipnotismo y la sugestión, que treinta años antes habían constituido los "primeros esbozos de una psicoterapia científica" (JANET, 1908, p. 70).

${ }^{20}$ Cabría preguntarse si, para Janet, tener que ocuparse del psicoanálisis (y no de sus propias doctrinas) constituía o no un hecho halagador. En todo caso, iba a ingeniárselas para hacer ambas cosas.

${ }^{21}$ Resulta interesante la crónica que el psiquiatra ítalo-argentino José Ingenieros escribió desde París relatando estos hechos años más tarde, detallando las virtudes de los dos candidatos para ese cargo (INGENIEROS, 1906).

22 Hay que recordar que Jung acababa de conocer a Freud personalmente ese mismo año, mientras que había pasado un semestre estudiando con Janet entre 1902 y 1903 (MONAHAN, 2009). Jones, por su parte, apenas había comenzado a practicar el psicoanálisis el año anterior. Conoció a Jung en el congreso de Amsterdam, y recién se encontraría con Freud un año más tarde, en el congreso de Salzburgo (ROUDINESCO; PLON, 1997).

${ }^{23}$ Freud no solía concurrir a eventos no psicoanalíticos. En este caso, cambió su negativa inicial, entre otras razones, por la insistencia de Jung sobre la importancia estratégica del evento.

24 "A great gathering next year", The Dominion, 6, (1639), p. 3, 4 de enero de 1913.

25 "International Congress of Medicine", British Medical Journal, 1(2739), p.13751376 (28 de junio de 1913).

26 En realidad, Roudinesco presenta todo este parágrafo sobre el congreso de Londres como una reedición de la "batalla de Bouvines", la primera victoria de los francos sobre los teutones, de la cual se cumplirían 700 años en 1914. "Desde hacía tiempo, el mundillo de la psicopatología esperaba presenciar el combate feroz que debía oponer a Freud y a Janet. Cada uno de esos dos príncipes se postulaba como el único heredero del gran Charcot. Uno trataba al otro de impostor, y el otro decía que su rival era mentiroso e imbécil. Los dos aspiraban al título de fundador del psicoanálisis" (ROUDINESCO, 1994, p. 243-244).

${ }^{27}$ La cursiva es de Janet.

${ }^{28}$ La cursiva es de Janet. 
${ }^{29}$ La cursiva es nuestra.

${ }^{30}$ La cursiva es de Janet.

31 Según Roudinesco, como hijo de una alsaciana patriota, Janet padecía de "una terrible inhibición". "Habiendo aprendido la lengua alemana en su infancia, desarrolló contra ella una suerte de fobia que lo hacía inepto para leer los textos de Freud" (ROUDINESCO, 1997, p. 245). Sea cual fuere la causa, lo cierto es que el profesor de los anteojos redondos no parecía manejar el alemán.

32 En realidad, prácticamente todas las referencias a textos en alemán (ya sea de Freud, Ferenczi, Sadger u otros), habían sido extraídas de un trabajo del psicólogo norteamericano Rudolph Acher, quien en 1911 había publicado un artículo en el American Journal of Psychology en el que recopilaba una docena de recensiones de textos recientes (ACHER, 1911). De todos modos, su utilización de la bibliografía así obtenida, más que exhaustiva, parecía ser apresurada, como si se tratara de acumular citas de autoridad en vez de analizarlas. Por ejemplo, cometía errores groseros, como confundir un trabajo de Max Graf sobre Richard Wagner con un artículo escrito por Richard Wagner (a quien citaba como autor) sobre el complejo de Edipo... (GRAF, 1911; ACHER, 1911, p. 420, apud JANET, 1914a, p. 101).

${ }^{33}$ La idea de depresión era un nuevo nombre para el viejo concepto de "debilidad de síntesis", que iba a terminar imponiéndose en la obra de Janet tanto como en el vocabulario psiquiátrico.

${ }^{34}$ Ver nota 2.

${ }^{35}$ La cursiva es de J anet, que retomará este argumento en las conclusiones.

${ }^{36}$ La cursiva es nuestra.

37 Esta mención de Janet de la teoría de un "genio local" (genius loci, según su origen latino), se prestó a interpretaciones encontradas de parte de los historiadores. Para Henri Ellenberger, ese incidente "ha dado lugar a una de las leyendas más tenaces de la historia de la psiquiatría dinámica", en la medida en que Janet, al hacer alusión a la atmósfera de Viena "habría insultado a Freud", cuando en realidad, a través de Ladame, se estaba refiriendo a la teoría de Friedländer, que explicaba el interés de los vieneses en las patologías sexuales a partir de las publicaciones de Krafft-Ebing, entre otros (ELLENBERGER, 1976, p. 921). Para Élisabeth Roudinesco, en cambio, "esa mención iba a ser fatal para el filósofo, confirmando una leyenda de la que ya no podría deshacerse". "En Londres, por su falta de cuidado, se convirtió en el hombre que insultó a Freud, proclamando que el psicoanálisis era el producto de un demonio específicamente vienés" (ROUDINESCO, 1994, p. 254). Según veremos más adelante, de allí en más, Freud reaccionaría siguiendo una interpretación cercana a la de Roudinesco.

${ }^{38}$ Medio siglo más tarde, otro célebre psiquiatra francés, muy alejado de las ideas de Janet, interpretaría su propio conflicto con la IPA en términos muy similares...

${ }^{39} \mathrm{Al}$ no disponer de esa parte de las actas del Congreso (actualmente inhallables), sólo contamos con el relato de Ellenberger para reconstruir la intervención de Jung, que tampoco se reproduce en sus Obras completas. No obstante, hay un resumen publicado en 1914 en el Zentralblatt, por entonces órgano oficial de la IPA, firmado por un estudiante de medicina, "M.T.", que cita literalmente algunos pasajes de Jung. Por esa razón, nos referiremos a él como "Jung, 2014" (agradecemos la traducción de Johanna Hopfengärtner).

${ }^{40}$ En el debate, otros psicoanalistas iban a utilizar términos janetianos (como el automatismo psicológico) para defender las ideas freudianas.

${ }^{41}$ El término "psicología analítica" empezó a ser utilizado por Jung justamente en 1913, a partir del congreso de Munich. Ya hemos hecho las reservas del caso respecto del uso restringido del "análisis psicológico".

${ }^{42}$ Esa parte de las actas se reproduce como "Discussion", en Nicolas, 2004, p. 114119 (traducida al francés por Isabelle Saillot). Lamentablemente, la versión original ha sido imposible de de detectar.

43 Según Roudinesco, "T.A. Williams expresa una opinión mesurada sobre los 
servicios prestados por la investigación freudiana" (Roudinesco, 1994, p. 256). Sin embargo, el mismo Jones, en su correspondencia con Freud, lo cuenta entre los críticos (J ONES, 1913).

${ }^{44}$ Cabe recordar que, en 1919, a partir de sus disidencias con Eder, Jones iba a disolver la LPS para fundar la BPS (British Psychoanalytical Society). No obstante, Eder iba a volver al redil en 1923 (ROUDINESCO; PLON, 1997).

${ }^{45}$ Compárese esta cita textual con su interpretación por parte de É. Roudinesco: "Eder se burla del francés preguntándole cómo hace para declarar al psicoanálisis absurdo y reivindicar su paternidad" (ROUDINESCO, 1994, p. 256). Una vez más, Janet no reclama la paternidad del psicoanálisis. Ni es eso lo que Eder le critica.

${ }^{46}$ Llegó a ser secretario general de la Société d'Hypnologie et de Psychologie (bajo la presidencia de Jules Voisin), además de fundar y dirigir la Revue de I'hypnotisme que se publicó de 1888 a 1910. Durante la Gran Guerra, daría libre curso a sus ideas racistas. Por ejemplo, en 1915 publicó La Polychésie de la race allemande, donde, básicamente, postulaba que los alemanes defecaban demasiado (es lo que trataba de ilustrar con el neologismo polychésie) ya que tenían un intestino más largo (LEFRERE; BERCHE, 2010).

47 En 1878, Savage había fundado el Journal of Mental Science, junto con Daniel Hack Tuke y Thomas Clouston. A fines de los años '80 se dedicó exclusivamente a la práctica privada, atendiendo a célebres pacientes de la burguesía londinense, como Virgina Woolf. En 1909 fue designado para dar el discurso anual del Royal College of Physicians, ocasión para la que eligió el tema "Psicología experimental e hipnotismo".

${ }^{48}$ Cabe destacar que, después de todas las críticas que recordaban el rol de la sexualidad infantil, Janet hacía alusión al "desarrollo del pensamiento en la infancia", algo más apropiado para referirse a Wallon que a Freud.

${ }^{49}$ Esto contradice la versión de Roudinesco, según la cual Jung hizo su intervención en inglés y estaba "orgulloso de su sintaxis inglesa". Ver ut supra.

50 "Y ahora creo que la causa va a triunfar en Inglaterra".

${ }^{51}$ Literalmente, "golpear el hierro cuando aún está caliente". Es decir, aprovechar la coyuntura favorable.

${ }^{52}$ Un año antes, ya se había publicado en Boston una versión en inglés de ese mismo comentario (J ANET, 1915).

${ }^{53}$ Agradecemos la traducción de Agustín Kripper.

54 Aunque no hayamos podido localizar ningún artículo de Ribot al respecto, lo cierto es que en la famosa revista que él dirigía, entre 1904 y 1906, aparecieron varias reseñas elogiosas sobre los trabajos de Mercante

${ }^{55}$ Carta de V. Mercante a H. Piéron del 21 de enero de 1905. "Fondo Piéron", París, Archives nationales de France, AP 8.

${ }^{56}$ Véase el impacto de la obra de Janet en diversos autores argentinos de la época en TALAK, 2007.

57 En ese mismo libro, incluso, Mercante iba a referirse a un supuesto encuentro casual con Freud, a orillas del lago de Ginebra, sin precisar su fecha. En la reproducción del diálogo que se habría producido entre ellos (real o imaginario), Freud le servía, antes que nada, para poner de relieve el problema de la psicología genética y su relación con la herencia, no tanto psicológica como biológica. En otra escala de su viaje, Mercante también iba a mostrar su interés por el simbolismo de los sueños con Sante De Sanctis, el máximo exponente de la psicología científica italiana. De modo que, en ese viaje a Europa, Mercante eligió hablar de la interpretación de los sueños con un discípulo de Lombroso, mientras que habría reservado a Freud para charlar sobre las relaciones entre el sexo, la raza y la educación (MERCANTE, 1927).

${ }^{58}$ A partir de su segunda edición, en 1906, cambió su nombre por el de Histeria y sugestión. Psicología clínica.

${ }^{59}$ Así lo indica la revista La Semana Médica del 6 de octubre de 1932, donde se 
publica una síntesis de la conferencia dada por Janet el 23 de septiembre (ROMERO, 2007, J ANET; LEGUEU, 1935).

${ }^{60}$ Putnam había sido presidente de la American Neurological Association, y, en un principio, había sido hostil al psicoanálisis. Münsterberg había hecho su doctorado en Leipzig, bajo la dirección de Wundt. En 1892, invitado por William James, se hizo cargo del laboratorio de psicología de la universidad de Harvard, accediendo a la presidencia de la APA en 1898. En cuanto a Meyer, formado en Suiza, Francia, Inglaterra y Alemania, iba a desempeñar en EEUU un rol muy importante en el desarrollo del movimiento de la "higiene mental".

${ }^{61}$ Nótese que Jones omitía la versión castellana (lo cual no resulta sorprendente), pero también pasaba por alto la versión alemana, publicada en el que hasta entonces era el órgano oficial de la IPA (JANET, 1914b). Por otra parte, su propia crítica de la crítica iba a ser publicada en alemán un año más tarde, en el Zeitschrift (J ONES, 1916).

${ }^{62}$ Los historiadores se basan en una carta de Édouard Pichon a Henri Ey, fechada el 14 de junio de 1939.

${ }^{63}$ Ruth Lays introduce un matiz en este punto. Según ella, para Janet "la memoria concebida como decir la verdad [truth-telling] está sobreestimada, pero la memoria concebida como narración es crucial" (LAYS, 2000, p. 117). 